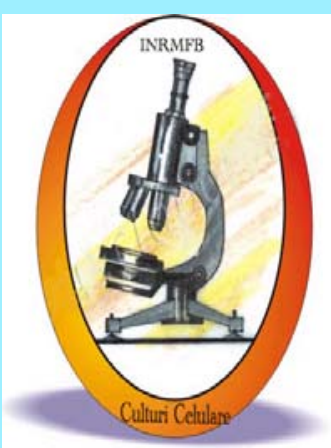

Editie in Limba Engleza

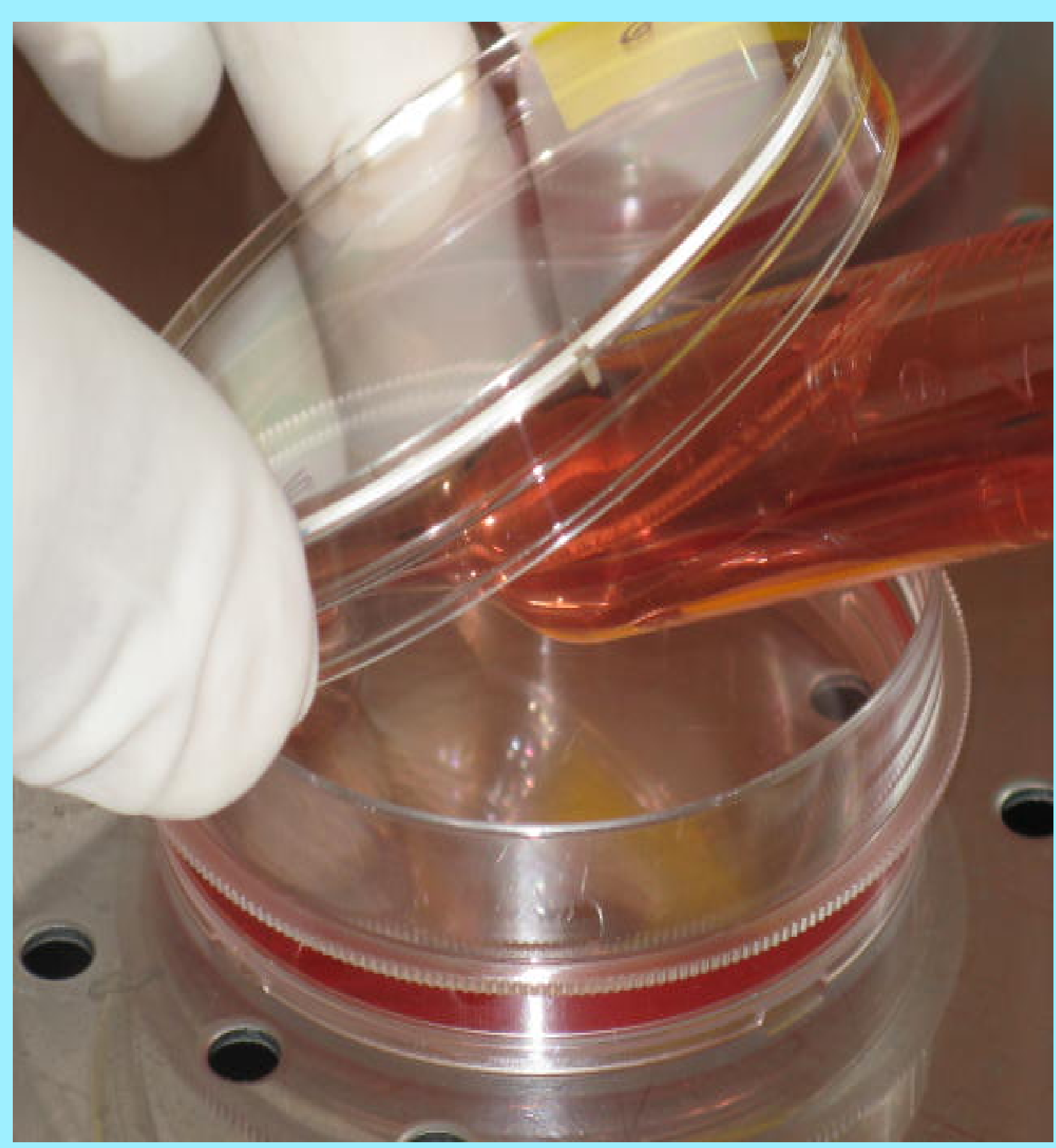

Vol.2, Nr.4, 2011

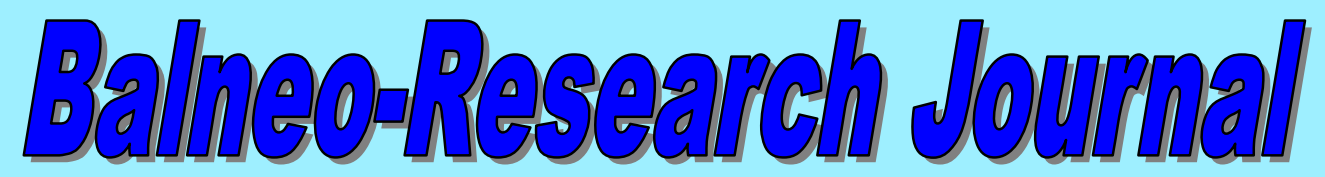

English Edition

ISSN 2069-7597

ISSN-L 2069-7597 
EDITOR: Constantin Munteanu, Ph.D., National Institute of Rehabilitation, Physical Medicine and Balneoclimatology, Romania

\section{Consiliul Editorial}

- Prof. Dr. Müfit Zeki KARAGÜLLE, MD, PhD, President of International Society of Medical Hydrology and Climatology, Department of Medical Ecology and Hydroclimatology, Istambul Medical Faculty of Istambul University, Turkey;

- Dr. Horia Lazarescu, Medic Endocrinolog, Institutul National de Recuperare Medicina Fizica si Balneoclimatologie din Bucuresti

- Prof. Dr. Constantin Cosma, Şef Catedra Fizica, Chimia şi Ingineria Mediului, Facultatea de Ştiința Mediului, Universitatea Babeş-Bolyai Cluj-Napoca, Romania;

- Ass. Prof. Dr. Delia Cintezã, PhD., University of Medicine and Pharmacy "Carol Davila" Bucharest, Romania;

- Dr. Daniela Poenaru, PhD., University of Medicine and Pharmacy "Carol Davila" - Bucharest, Romania;

- Ass. Prof. Dr. Olga Surdu, PhD., Balneary Sanatorium Techirghiol, Constanta, Romania;

- Ass. Prof. Dr. Liviu Enache, PhD., Universitatea de Ştiințe Agronomice şi Medicina Veterinara București, România;

- Ass. Prof. Dr. Gheorghe Stoian, PhD., Department of Biochemistry and Molecular Biology, University of Bucharest, Faculty of Biology, Bucharest, Romania;

- Ass. Prof. Dr. Claudiu Mãrgãritescu, Senior Pathologist at Emergency Clinical Hospital from Craiova, University of Medicine and Pharmacy from Craiova, Romania;

- CP II, Iuri Simionca, Dr.B., Ph.D., National Institute of Rehabilitation, Physical Medicine and Balneoclimatology, Bucharest, Romania;

- Gina Gãlbeazã, National Institute of Rehabilitation, Physical Medicine and Balneoclimatology, Bucharest, Romania;

- Mihai Hoteteu, Ph.D., National Institute of Rehabilitation, Physical Medicine and Balneoclimatology, Bucharest, Romania;

- Diana Munteanu, M.Sc., National Institute of Rehabilitation, Physical Medicine and Balneoclimatology, Bucharest, Romania.

- Liana Gheorghievici, M.Sc., National Institute of Rehabilitation, Physical Medicine and Balneoclimatology, Bucharest, Romania.

Published by

Editura Balnearã - http://bioclima.ro/EDITURA.htm

E-mail: secretar@bioclima.ro

B-dul Ion Mihalache, 11A, Sector 1, Bucharest, Romania

ISSN 2069-7597

ISSN- L 2069-7597 


\section{Content}

- EDITORIAL - Constantin Munteanu;

\section{ORIGINAL PAPERS}

- Estrogenic compounds-endocrine disruptors-Constantin Munteanu, Mihai Hoteteu

- Artemia salina - Mioara Dumitrascu

- Iodine waters - Iliuțã Alexandru

- Bãile Tuşnad Resort - Constantin Munteanu

2012 AGENDA 


\section{EDITORIAL}

\section{Constantin Munteanu}

In this editorial I will try an transparent exercise by answering of some questions like: „What is missing of Romanian balneology to take their deserved place on the European and global health tourism map? Where are we in this regard, what we have to do, how we praise and especially what obstacles prevent us to find the way to the light of local spa's success tourist destinations?"

I experienced a few times, on different occasions with such questions throughout the year that just ending, and provide some examples:

\section{Romania Actualitati Radio Interview}

In the last years, many people began to travel to other countries to treat various medical problems and which, in their country would imply very high costs.

Thus, these people manage to do treatments at least as good, but much cheaper and visit a foreign country simultaneously.

As regards Romania, the emphasis will be placed on spas, according to Director General Ministry of Tourism, Carmen Moraru

"We intend to take advantage of tourism potential that Romania has in this field and to promote medical tourism packages. When it comes to therapeutic factors, Romania is the best in this field. We have mineral water, sapropelic mud and all sorts of such curative and therapeutical factors".

"We are also concerned with improving the tourism and general infrastructure in balneoclimateric resorts that we have. Only this year are financed infrastructure projects in public-public partnership of about 60 million from the state budget, "said Carmen Moraru.

About how prepared are balneoclimateric resorts in Romania to receive foreign tourists, Dr. Constantin Munteanu from the National Institute of Rehabilitation, Physical Medicine and Balneoclimatology says that at present they have potential.
"There have natural therapeutic factors, have the baseline, we have resort for a long time tradition, we have distinguished specialists, we say so many arguments to say that we can base our future on a quality balneary tourism" said Constantin Munteanu.

If in the natural resources there is no doubt that they are sufficient to support this type of tourism, there remains the problem of human resources because more and more Romanian doctors, going abroad.

In an interview for Day Event I answered to a similar question: "We have all". According to Constantin Munteanu, a researcher at the National Institute of Rehabilitation, Physical Medicine and Balneoclimatology, Romania has a great potential, and if interested investors will invest more, we could compete even Poland, the number one in terms of services offered by saline.

"We have a huge potential. If we arrange salt mines, a process that has already begun, we could surpass Poland in Turda salt mine, which was modernized with EU funds ". According to Munteanu, most investments are subject to the decisions taken at local level, but also by private investors, because most treatment facilities have been privatized.

Analyzing retrospectively, I would start with the following thought: "Am I able to answer such questions? Researcher in cell biology of natural therapeutic factors; would say yes, in the extent that I can look the balneary phenomenon from the "objective researcher balcony."

On the other hand, maybe not, because I do not are belong nor from the structures of the Ministry of Tourism, nor of tourism investors nor connection other than being a tourist sometimes and I have not, and still .....

My answer short: Romania needs a chance to show that deserves attention, needs the infrastructure, an effective promotion of scientific arguments favorable external image in magazines, the strength of conviction of those who represent the interests of this area and especially the "Ambassadors like Prince Charles" a lover of lands mioritical. 


\section{Romanian Association of Balneology \\ Bulevardul Ion Mihalache, 11A, Sector 1, Bucureşti, Telefon/Fax: 021-3186458 \\ E-mail : secretar@bioclima.ro, $\underline{\text { http://bioclima.ro }}$}

\section{Dear collaborators,}

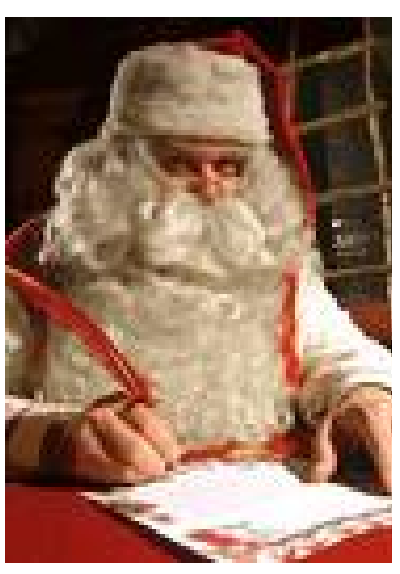

Year 2011 was the "first year" in the existence of the Romanian Association of Balneology. As every beginning, significant the emotion of a new road, the joy of first steps into the balneary world and a smile of confidence in our objectives.

Together with our collaborators, the sponsors, those passionate about their work in the balneary field, along with the warm-hearted, this year wewere able to organize in spring, The Ninth National Conference of Balneology in Neptune, to organize in autumn The First Conference National speleotherapy in Turda, to organize specialized courses, to continue the publication of 4 issues of BalneoResearch Journal with Romanian and English editions, to publish books useful to the guild and participate in international scientific meetings in our field of interest. All

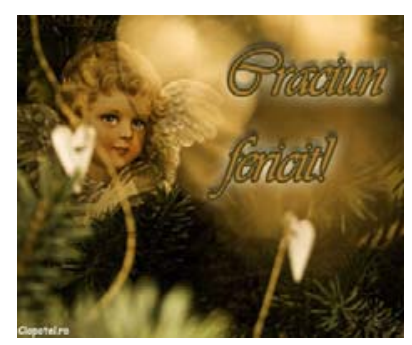
these facts are presented on the website http://bioclima.ro.

The year 2012 brings new hope in the success of the objectives for which we exist. We believe in our ability to participate in the development of balneary tourism sector and we assumed to contribute through scientific research and educational projects and to promote the balneary resources of our country to the progress of the local balneary phenomenon.

Christmas and New Year celebrations occur joy in our

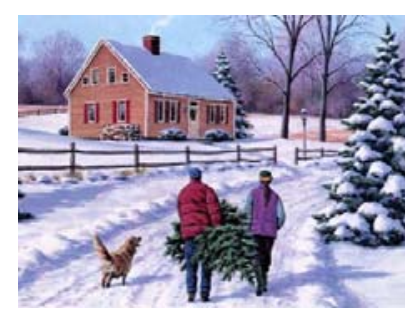
souls and find naturally to share with all who are part of our balneary Universe. We have now the opportunity to send everyone a traditional Happy Birthday, the best wishes for health, personal achievement and much power for work to turn the optimism into a general feeling.

With this occasion, we want to thank all collaborators and partners, especially the sponsors that have been togethe, we will be happy with the belief that opportunities for collaboration in the future. 


\section{8th World Congress}
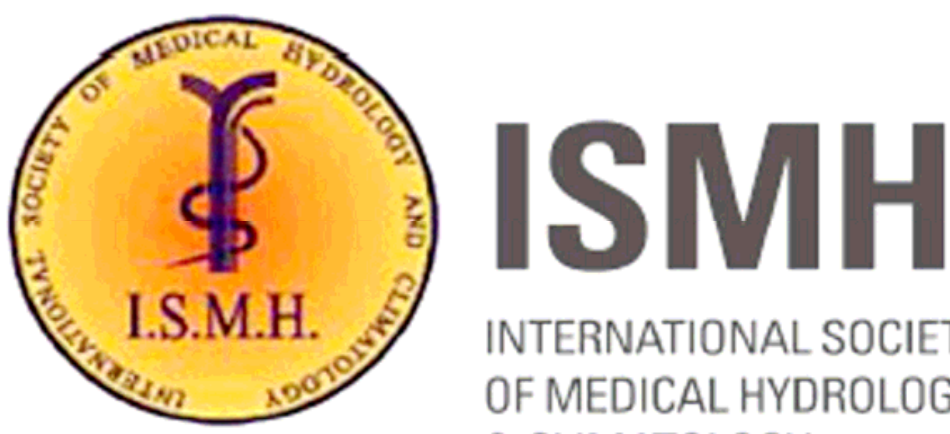

INTERNATIONAL SOCIETY OF MEDICAL HYDROLOGY \& CLIMATOLOGY

«Medical Hydrology and Balneology:

\section{Environmental Aspects »}

$$
\begin{aligned}
& \text { Lanjarón - Granada } \\
& \text { June } 20 \text { - 23, } 2012
\end{aligned}
$$

Website: www.ismh2012.com 


\section{Estrogenic compounds - endocrine disruptors}

Constantin Munteanu, Mihai Hoteteu

\section{Institutul Național de Recuperare, Medicina Fizica şi Balneoclimatologie}

Endocrine disruptors (polychlorinated biphenyls, dichlorodiphenyl-trichloroethane [DDT], dioxin, and some pesticides) are estrogen-like and anti-androgenic chemicals in the environment. They mimic natural hormones, inhibit the action of hormones, or alter the normal regulatory function of the endocrine system and have potential hazardous effects on male reproductive axis causing infertility. Although testicular and prostate cancers, abnormal sexual development, undescended testis, chronic inflammation, Sertoli-cell-only pattern, hypospadias, altered pituitary and thyroid gland functions are also observed, the available data are insufficient to deduce worldwide conclusions. ${ }^{[1]}$

The development of intra-cytoplasmic sperm injection (ICSI) is beyond doubt the most important recent breakthrough in the treatment of male infertility, but it does not necessarily treat the cause and may inadvertently pass on adverse genetic consequences. Many well-controlled clinical studies and basic scientific discoveries in the physiology, biochemistry, and molecular and cellular biology of the male reproductive system have helped in the identification of greater numbers of men with male factor problems. ${ }^{[1]}$

Newer tools for the detection of Ychromosome deletions have further strengthened the hypothesis that the decline in male reproductive health and fertility may be related to the presence of certain toxic chemicals in the environment. Thus the etiology, diagnosis, and treatment of male factor infertility remain a real challenge. Clinicians should always attempt to identify the etiology of a possible testicular toxicity, assess the degree of risk to the patient being evaluated for infertility, and initiate a plan to control and prevent exposure to others once an association between occupation/toxicant and infertility has been established. ${ }^{[1]}$
Endocrine disruptors are chemicals that interfere with endocrine (or hormone system) in animals, including humans. These disruptions can cause cancerous tumors, birth defects, and other developmental disorders. Specifically, they are known to cause learning disabilities, severe attention deficit disorder, cognitive and brain development problems, deformations of the body (including limbs); sexual development problems, feminizing of males or masculine effects on females, etc.

Any system in the body controlled by hormones, can be derailed by hormone disruptors. The critical period of development for most organisms is between the transition from a fertilized butt, into a fully formed infant. As the cells begin to grow and differentiate, there are critical balances of hormones and protein changes that must occur. Therefore, a dose of disrupting chemicals can do substantial damage to a developing fetus (baby). Whereas, the same dose may not significantly affect adult mothers.

Endocrine disruptors are substances that "interfere with the synthesis, secretion, transport, binding, action, or elimination of natural hormones in the body that are responsible for development, behavior, fertility, and maintenance of homeostasis (normal cell metabolism)." ${ }^{[2]}$ They are sometimes also referred to as hormonally active agents, ${ }^{[3]}$ endocrine disrupting chemicals, ${ }^{[4]}$ or endocrine disrupting compounds(EDCs). ${ }^{[5]}$

EDC studies have shown that endocrine disruptors can cause adverse biological effects in animals, and low-level exposures also cause similar effects in human beings. ${ }^{[6]}$ The term endocrine disruptor is often used as synonym for xenohormone although the later can mean any naturally occurring or artificially produced compound showing hormone-like properties (usually binding to certain hormonal receptors). 
The term endocrine disruptor was coined at the Wingspread Conference Centre in Wisconsin, in 1991. One of the early papers on the phenomenon was by Theo Colborn in 1993. ${ }^{[7]}$ In this paper, she stated that environmental chemicals disrupt the development of the endocrine system, and that effects of exposure during development are often permanent. Although the endocrine disruption has been disputed by some, ${ }^{[8]}$ work sessions from 1992 to 1999 have generated consensus statements from scientists regarding the hazard from endocrine disruptors, particularly in wildlife and also in humans. ${ }^{[9]}$

The Endocrine Society released a scientific statement outlining mechanisms and effects of endocrine disruptors on "male and female reproduction, breast development and cancer, prostate cancer, neuroendocrinology, thyroid, metabolism and obesity, and cardiovascular endocrinology," and showing how experimental and epidemiological studies converge with human clinical observations "to implicate EDCs as a significant concern to public health." The statement noted that it is difficult to show that endocrine disruptors cause human diseases, and it recommended that the precautionary principle should be followed. ${ }^{[3]} \mathrm{A}$ concurrent statement expresses policy concerns. $^{[10]}$

Endocrine disrupting compounds encompass a variety of chemical classes, including drugs, pesticides, compounds used in the plastics industry and in consumer products, industrial by-products and pollutants, and even some naturally produced botanical chemicals. Some are pervasive and widely dispersed in the environment and may bio-accumulate. Some are persistent organic pollutants (POP's), and can be transported long distances across national boundaries and have been found in virtually all regions of the world, and may even concentrate near the North Pole, due to weather patterns and cold conditions. ${ }^{[11]}$ Others are rapidly degraded in the environment or human body or may be present for only short periods of time. ${ }^{[12]}$

Health effects attributed to endocrine disrupting compounds include a range of reproductive problems (reduced fertility, male and female reproductive tract abnormalities, and skewed male/female sex ratios, loss of fetus, menstrual problems ${ }^{[13]}$ ); changes in hormone levels; early puberty; brain and behavior problems; impaired immune functions; and various cancers. ${ }^{[14]}$

One major objection to the theory of endocrine disruptors is the dosage effect. There is a large gap between high exposures seen in a laboratory experiment versus the relatively low levels found in the environment. ${ }^{[16][17]}$

Critics argue that dose-response relationship data suggest that the amounts of the chemicals actually in the environment are too low to cause an effect. A consensus statement by the Learning and Development Disabilities Initiative rebuts this criticism arguing "The very low-dose effects of endocrine disruptors can not be predicted from high-dose studies, which contradicts the standard 'dose makes the poison' rule of toxicology. Nontraditional dose-response curves are referred to as nonmonotonic dose response curves." ${ }^{[15]}$ Furthermore, endocrine disrupting effects have been noted in animals exposed to environmentally relevant levels of some chemicals. For example, researchers have found that a common flame retardant, PBDE47 , affects the reproductive system and thyroid gland of female rats in doses of the order of those to which humans are exposed. ${ }^{[18]}$

The dosage objection could also be overcome if low concentrations of different endocrine disruptors were synergistic, which was asserted in a paper by Arnold. ${ }^{[19]}$ This paper was published in Science in June 1996, and was one reason for the passage of the Food Quality Protection Act of 1996. ${ }^{[20]}$ The results could not be confirmed with the same and alternative methodologies, ${ }^{[21]}$ and the original paper was retracted, ${ }^{[22]}$ with Arnold found to have committed scientific misconduct by the United States Office of Research Integrity. ${ }^{[23]}$ Subsequent papers by other authors demonstrated that low concentrations of endocrine disruptors can have synergistic effects in amphibians, but it is not clear that this is an effect mediated through the endocrine system. ${ }^{[24]}$

The conventional relationship (more exposure equals higher risk) has been challenged by some studying endocrine disruptors. For example, it has been claimed that Tamoxifen and some phthalates have fundamentally different (and harmful) effects on the body at low doses than at high doses. ${ }^{[25]}$ 
Food is a major mechanism by which people are exposed to pollutants.

Diet is thought to account for up to $90 \%$ of a person's PCB and DDT body burden. ${ }^{[26]}$ In a study of 32 different common food products from three grocery stores in Dallas, fish and other animal products were found to be contaminated with PBDE. ${ }^{[27]}$ Since these compounds are fat soluble, it is likely they are accumulating from the environment in the fatty tissue of animals we eat. Some suspect fish consumption is a major source of many environmental contaminates. Indeed, both wild and farmed salmon from all over the world have been shown to contain a variety of manmade organic compounds. ${ }^{[28]}$

With the increase in household products containing pollutants and the decrease in the quality of building ventilation, indoor air has become a significant source of pollutant exposure. $^{[29]}$

Residents living in homes with wood floors treated in the 1960s with PCB-based wood finish have a much higher body burden than the general population. ${ }^{[30]}$ A study of indoor house dust and dryer lint of 16 homes found high levels of all 22 different PBDE congeners tested for in all samples. ${ }^{[31]}$ Recent studies suggest that contaminated house dust, not food, may be the major source of PBDE in our bodies. ${ }^{[32]}$ One study estimated that ingestion of house dust accounts for up to $82 \%$ of our PBDE body burden. ${ }^{[33]}$

Research conducted by the Environmental Working Group found that 19 out of 20 children tested had levels of PBDE in their blood 3.5 times higher than the amount in their mothers' blood. ${ }^{[34]}$ It has been shown that contaminated housedust is a primary source of lead in young children's bodies. ${ }^{[35]}$ It may be that babies and toddlers ingest more contaminated housedust than the adults they live with, and therefore have much higher levels of pollutants in their systems.

\section{References}

1. Sikka SC, Wang R. - Endocrine disruptors and estrogenic effects on male reproductive axis. Asian J Androl. 2008 Jan;10(1):13445.

2. Brake A, Krause W. Decreasing quality of semen. BMJ 1992; 305: 1498.
3. Lewis SE, Aitken RJ. DNA damage to spermatozoa has impacts on fertilization and pregnancy. Cell Tissue Res 2005; 322: $33-41$.

4. Olsen GW, Bodner KM, Ramlow JM, Ross CE, Lipshultz LI. Have sperm counts been reduced 50 percent in 50 years? A statistical model revisited.Fertil Steril 1995; 63: 887-93.

5. Fisch H, Goluboff ET, Olson JH, Feldshuh J, Broder SJ, Barad DH. Semen analyses in 1283 men from the United States over a 25-year period: No decline in quality. Fertil Steril 1996; 65:

1009

14. | PubMed | ChemPort |

6. Parvinen M, Lahdetie J, Parvinen LM. Toxic and mutagenic influences on spermatogenesis. Arch Suppl 1984; 7: 128-39.

7. Niederberger C. Exposure to persistent organochlorine pollutants associates with human sperm Y:X chromosome ratio. Hum Reprod 2005; 20: 1903-9.

8. Guillette LJ Jr, Gross TS, Masson GR, Matter JM, Percival HF, Woodward AR. Developmental abnormalities of the gonad and abnormal sex hormone concentrations in juvenile alligators from contaminated and control lakes in Florida. Environ Health Perspect 1994; 102: $\quad 680$ 8. | PubMed | ISI | ChemPort |

9. Kavlock RJ, Perreault SD. Multiple chemical exposure and risks of adverse reproductive function and outcome. In: Toxicological of Chemical Mixtures: From Real Life Examples to Mechanisms of Toxicology Interactions. Yang RS, editor. Academic Press: Orlando. 1994; p 245-97.

10. Sokol RZ. Hormonal effects of lead acetate in the male rat: mechanism of action. Biol Reprod 1987; 37: 1135-8.

11. Sikka SC. Gonadotoxicity. In: Male Infertility and Sexual Dysfunction. Hellstrom WJ, editor. Springer-Veerlag, New York. 1997; p 292-306.

12. Cheek AO, McLachlan JA. Environmental hormones and the male reproductive system. $J \quad$ Androl 1998; 19: 510. | ChemPort |

13. McLachlan JA, Arnold SF. Environmental estrogens. Amer Sci 1996; 84: 452-61.

14. Colborn T, vomSaal FS, Soto AM. Developmental effects of endocrine- 
disrupting chemicals in wildlife and humans. Env Health Prospect 1993;1101: 378-84.

15. Sikka SC, Nigun G. Reproductive Toxicity of Organophosphate and Carbamate Pesticides. In: Toxicology of Organophosphate and Carbamate Compounds. Gupta RC, editor. Elsevier Academic Press: New York. 2005; Chapter 32, p 447-62.

16. Kelce WR, Monosson E, Gamcsik MP, Laws SC, Gray LE Jr. Environmental hormone disruptors: evidence that vinclozolin developmental toxicity is mediated by antiandrogenic metabolites. Toxicol Appl Pharm 1994; 126: 276-85.

17. Friberg L, Piscator M, Nordberg GF. Cadmium in the environment, 2nd edition. Cleveland: CRC Press Inc., 1974; p 37-53.

18. Rosselli M, Dubey RK, Imthurn B, Macase E, Keller PJ. Effects of nitric oxide on human spermatozoa: evidence that nitric oxide decreases sperm motility and induces sperm toxicity. Hum Reprod 1995; 10: 1786-90. | PubMed | ChemPort |

19. Oats RD, Lipshultz LI. Fertility and testicular function in patients after chemotherapy and radiotherapy. In: Advances in Urology, vol 2. Lytton B, editor. Chicago: Mosby Year Book. 1989; p 55-83.

20. Rowley MJ, Leach DR, Warner GA, Heller CG. Effects of graded doses of ionizing radiation on the human testis. Radiat Res 1974; 59: 665-78.

21. Ogilvy-Stuart AL, Shalet SM. Effect of radiation on the Human reproductive system. Environ Health Perspect 1993; 101 Suppl 2: 109-16.

22. Knuth UA, Maniera $H$, Nieschlag E. Anabolic steroids and semen parameters in bodybuilders. Fertil Steril 1989; 52: 10417.

23. Jarow JP, Lipshultz LI. Anabolic steroidinduced hypogonadotropic hypogonadism. Am J Sports Med 1990; 18: 429-31. | Article | PubMed | ChemPort |

24. Ericsson RJ, Baker VF. Binding of tetracycline to mammalian spermatozoa.Nature 1967; 214: 4034. | Article | PubMed | ISI | ChemPort |
25. Schlegel PN, Chang TS, Maeshall FF. Antibiotics: potential hazards to male fertility. Fertil Steril 1991; 55: 23542. | PubMed | ChemPort |

26. Shalet SM. Effects of cancer chemotherapy on testicular function of patients. Cancer Treat Rev 1980; 7: 41152.

27. Spitz S. The histological effects of nitrogen mustards on human tumors and tissues. Cancer 1948; 1: 383-8.

28. Meistrich ML. Quantitative correlation between testicular stem cell survival, sperm production, and fertility in mouse after treatment with different cytotoxic agents. $J$ Androl 1982; 3: 58-68.

29. Qiu J, Hales BF, Robaire B. Adverse effects of cyclophosphamide on progeny outcome can be mediated through posttesticular mechanisms in the rat. Biol Reprod 1992; 46: 926-31.

30. Trasler JM, Hales BF, Robaire B. A time course study of chronic paternal cyclophosphamide treatment of rats: effects on pregnancy outcome and the male reproductive and hematologic systems. Biol Reprod 1987; 37: 317-26.

31. Sherins RJ, DeVita VT Jr. Effect of drug treatment for lymphoma on male reproductive capacity. Ann Intern Med 1973; 79: 216-20.

32. Parvinen M, Lahdetie J, Parvinen LM. Toxic and mutagenic influences on spermatogenesis. Arch Suppl 1984; 7: 128-39.

Toxicol

33. Manavathi B, Kumar R. Steering estrogen signals from the plasma membrane to the nucleus: two sides of the coin. $J$ Cell Physiol 2006; 207:

594604. | Article | PubMed | ISI | ChemPort |

34. Wilson CA, Leigh AJ, Chapman AJ. Gonadotrophin glycosylation and function. $J$ Endocrinol 1990; 125: 3-14.

35. Cooper RL, Goldman JM, Rehnberg GL, McElroy WK, Hein JF. Effects of metal cations on pituitary hormone secretion in vitro. J Biochem Toxicol 1987; 2: 241-9. 


\section{Artemia salina}

\section{Mioara Dumitrascu \\ SC Biosafety SRL-D;}

Artemia salina (L.) is a primitive aquatic arthropod (salt lakes) of the Artemiidae family (figure 1) with an age of about 100 million years. Linný (1758) described it as Cýncer salinus but 61 years later, Leach (1819) transferred it to Artemia salina.

It was reported for the first time in Urmia Lake in 982 by a Iranian geographer (Asem, 2008).

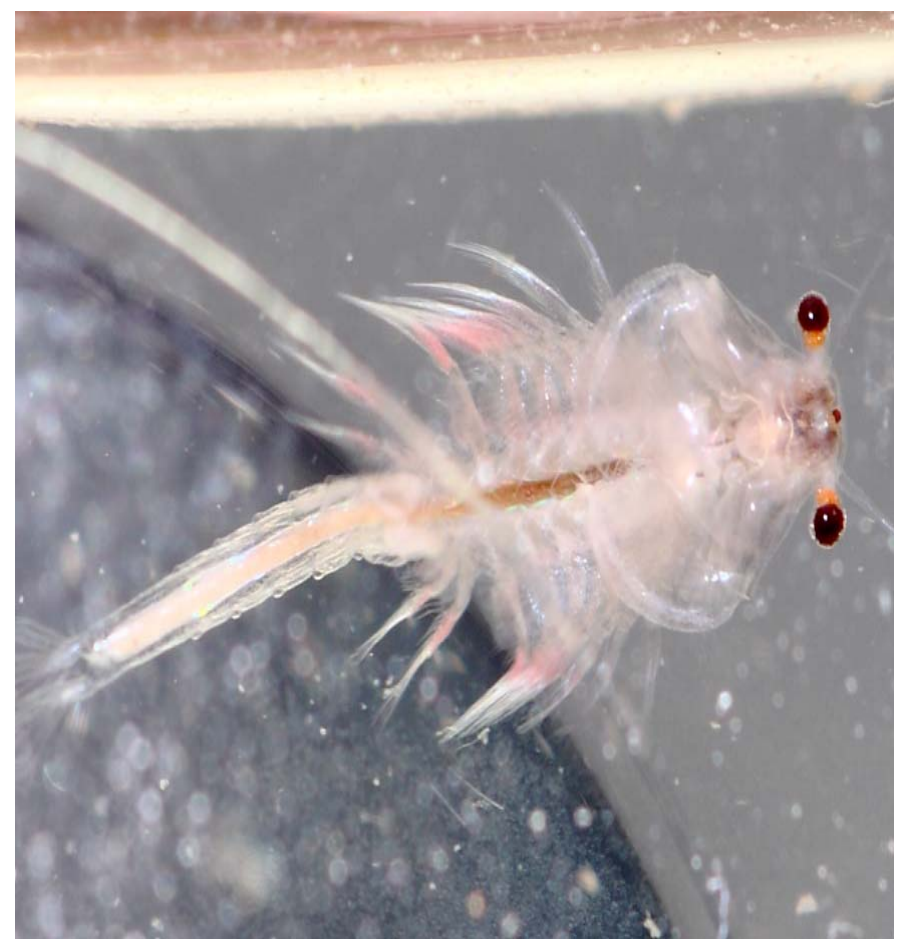

Figura 1. Artemia salina

\section{Species ecology}

Artemia salina lives only in lakes and ponds with high salinity, which varies between 60-300 ppt. It was also discovered in Elkhorn Slough (California), which communicates directly with the sea. It is a species endemic to the Mediterranean, but is found on all continents (figure 2).

In our country is reported in salt lakes (Bear Lake, Ocna Sibiu, Techirghiol, Braila Salt Lake, etc.) contributing to the formation of sapropelic mud used in peloidotherapy.

A. salina is associated with current or past commercial exploitation of salt (Abatzopoulos et al., 2002, quoted by Abatzopoulos et al., 2010).

Can tolerate large amounts of salt (up to 300 grams of salt per liter of water) and can live in quite different solutions of seawater such as potassium permanganate and silver nitrate.Iodine, which is found frequently in salt for human use, is harmful to this species.

\begin{tabular}{|l|l|}
\hline \multicolumn{2}{|c|}{ Scientific classification } \\
\hline Kingdom: & Animalia \\
\hline Phylum: & Arthropoda \\
\hline Subphylum: & Crustacea \\
\hline Class: & Branchiopoda \\
\hline Order: & Anostraca \\
\hline Family: & Artemiidae \\
\hline Genus: & Artemia \\
\hline Species: & $\begin{array}{l}\text { Artemia salina } \\
\text { (Linnaeus, 1758) }\end{array}$ \\
\hline
\end{tabular}

These animals have the ability to reduce the osmotic pressure of haemolymph by $\mathrm{NaCl}$ excretion against the concentration gradient. Has been shown to developed a mechanism to maintain haemolymph extreme hypotonic in saline extreme media (Croghan, 1957).

Also, this species can survive in water with high oxygen deficiency. Minimum concentration of oxygen for an adult is very low, 0.5 milligrams per liter, and for naupliia even less than 0.3 milligrams per liter. Typical salt lakes have seasonal or cyclical droughts, periods when completely dry. During this process salt water concentrations ranging from ideal to barely tolerable. 


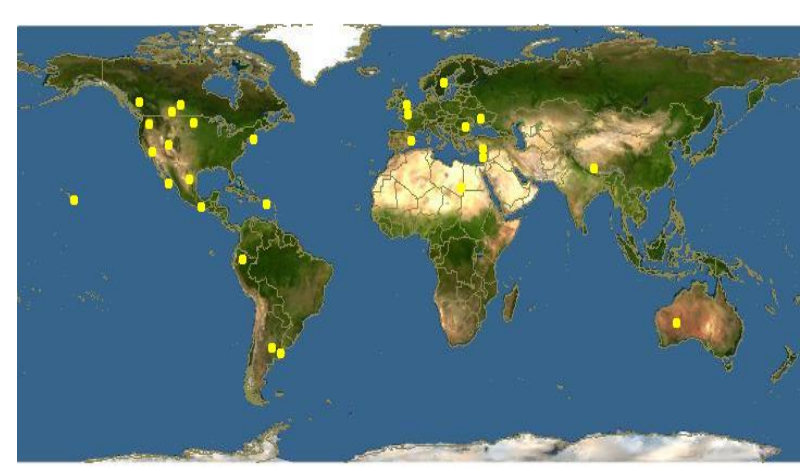

Figure 2. Artemia salina worldwide distribution (Global Biodiversity Information Facility Database http://www.discoverlife.org)

\section{Description}

The body consists of three segments: head, thorax and abdomen. The species presents sexual dimorphism, the main morphological differences between males and females were observed in maximum distance between compound eyes, length of first antenna, the width of the third abdominal segment, the total length, diameter of compound eye, length of abdomen.

The adult male reach to $8-10 \mathrm{~mm}$ long, and the female $10-12 \mathrm{~mm}$. Adults have three eyes and 11 pairs of legs.

Adult color varies depending on the concentration of salt in the water from green tored (high concentrations are red). Their blood contains pigment hemoglobin.

Lack of competition in this extreme environment allows them to develop large populations when conditions are suitable for reproduction (heat, sunlight, wide range of salt concentrations).

This organism can withstand long periods of drought and cyst stage to resume the life cycle when conditions are suitable for development and reproduction.

Males have two reproduction organs. The uterus of one female of A. salina may contain up to 200 eggs. It is an oviparous and ovoviviparous species.

The two methods of reproduction alternates depending on the conditions of life: are ovoviviparous when they are favorable and when become unfavorable, tend to be oviparous.

They produce eggs, which float on water and can develop either directly into nauplia (larvae) or unfavorable environmental conditions (water drying) is transformed into cysts (dormant forms of life) that can survive long periods of drought. If environmental conditions improve, cysts are "re-vitalizing" and hatch nauplia.

Under natural conditions Artemia salina feeds with algae, protozoa and detritus. Feeding mode is active non-selective filter; removes suspended particles less than 40-60 $\mathrm{mm}$.

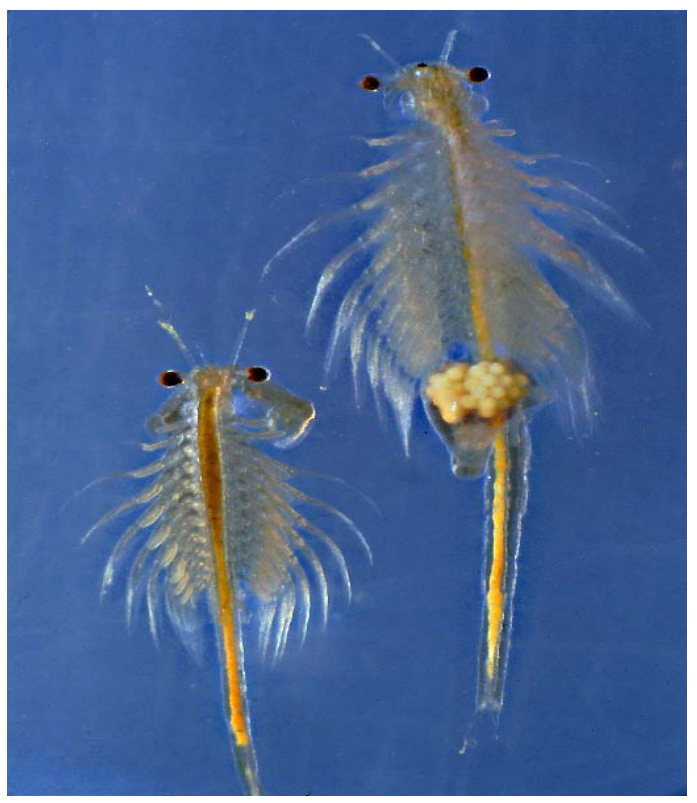

Figure 4. Individuals of the Artemia salina

\section{Life cycle}

Mode of reproduction is controlled by environmental factors: the concentration of oxygen in water and its fluctuation, the type of food, salinity, etc. (table 1). There was a correlation between water salinity level and method of reproduction. Ovoviviparous to less than 150 ppt salinity and oviparous predominantly between $150-200$ ppt salinity

Table 1. The modalities of Artemia salina reproduction

\begin{tabular}{|l|l|}
\hline \multicolumn{2}{|c|}{ REPRODUCTION } \\
\hline \multicolumn{1}{|c|}{ OVIPAROUS } & \multicolumn{1}{c|}{ OVOVIVIPAROUS } \\
\hline $\begin{array}{l}\text {-- low } \mathrm{O}_{2} \text {-content } \\
\text { (such as in high } \\
\text { salinity) }\end{array}$ & $\begin{array}{l}\text {-high oxygen content } \\
\text { (such as in low salinity) }\end{array}$ \\
\hline $\begin{array}{l}\text { - strong } \mathrm{O}_{2-} \\
\text { fluctuations }\end{array}$ & - minor $\mathrm{O}_{2}$-fluctuations \\
\hline $\begin{array}{l}\text { - Fe-rich food (such } \\
\text { as green algae) }\end{array}$ & $\begin{array}{l}\text { - Fe-low food (such as } \\
\text { organic debris) }\end{array}$ \\
\hline
\end{tabular}


Vol.2, Nr.4, 2011

Oviparous reproduction

After copulation fertilized egg develops into a gastrula stage and are surrounded by a tough brown crust consists of chitin, lipoproteins, etc.

Cysts thus formed are released into the water and must pass through a drying process. Only when this initial dehydration occurred, the cysts can get free larvae when conditions become favorable.

\section{Ovoviviparous reproduction}

The fertilized egg develops to the stage of gastrulă, but instead of being confined, still gastrula differentiate into female body, the larvae called nauplia. Eggs hatch nauplia which will have a whitish colour. Nauplia are free fins larvae.

Cysts $(0.2-0.3 \mathrm{~mm})$ turn into larvae water swimmer, nauplia $(0.45 \mathrm{~mm})$ in a period of $24-$ 36 hours. Complete hydration cyst takes about an hour. Depending on food availability, nauplia will reach adults (max. $12 \mathrm{~mm}$ ) within 3 weeks.

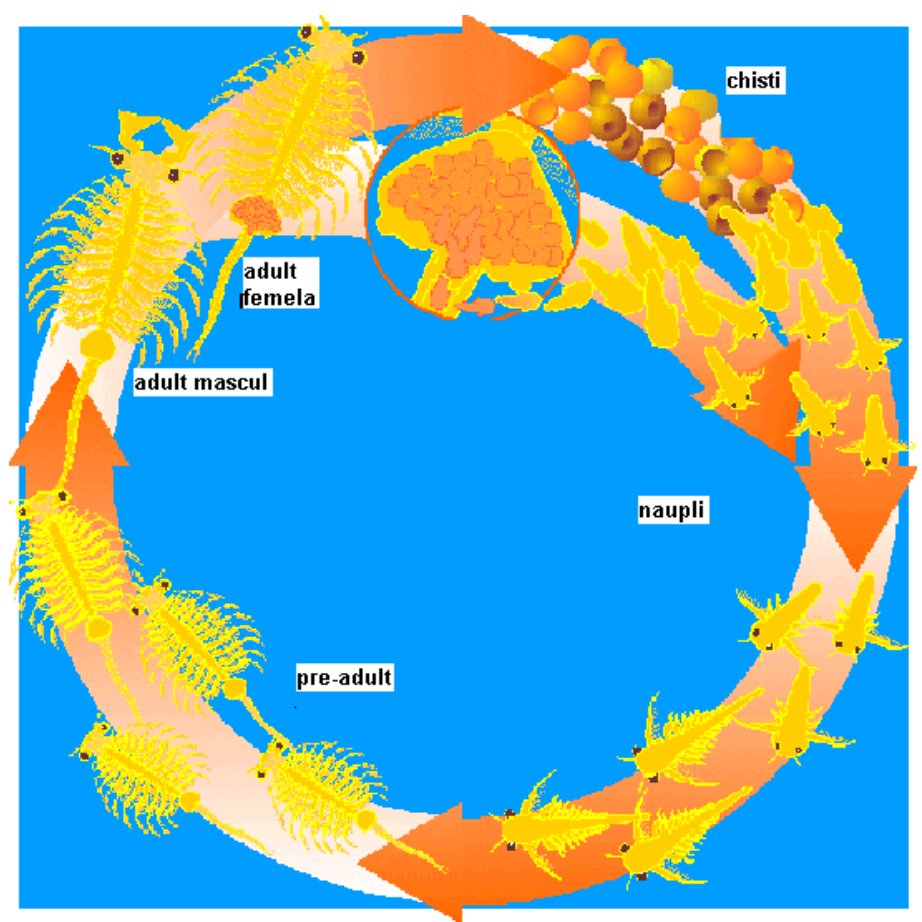

Figure 5. Artemis salina life cycle (http://brineshrimp.wordpress.com/)

Nauplia turns into reproductive adults that produce live young in rapid succession when conditions are favorable and cysts that can survive dry conditions for years if conditions begin to become less favorable.
In order to result free fins nauplia from cysts, they need water (hydration) and oxygen to initiate and complete the metabolism.

\section{$\Rightarrow \quad$ Cysts}

Cysts are very resistant to extreme conditions, lasts up to $80 y$ C. Hydrated cysts die at temperatures below $0 y ́ \mathrm{C}$ and greater than $40 y$ C. The higher salinity of $70 \mathrm{ppt}$, naupliia will not be able to hatch due to osmotic gradient too high. At less than 5 ppt salinity, cysts will hatch, but nauplia results will die quickly.

Dehydrated cysts measuring between 200270 microns and an average weight of 3.5 micrograms.

Cysts are able to survive in contact with aggressive liquids, extreme dryness, lack of of oxygen and pesticides influence. For example, in the United States in 1976, during a drilling operationin the Great Salt Lake in Utah, A. salina cysts were found in thesoil sample between two layers of salt. Carbon analysis showed that age radiactiv cysts would be 10,000 years. (artemiaworld.com ).

\section{$\Rightarrow \quad$ Nauplia}

Have optimal growth at $28{ }^{0} \mathrm{C}$ and $35 \mathrm{ppt}$. Lethal temperature limits are $0{ }^{\circ} \mathrm{C}$ and $37-38^{\circ}$ C.

Larvae have only one eye (photoreceptor). Later, it developed two eyes, but the initial eye remains, resulting three eyes. Nauplia are phototactic, while adults not. They swim through the water column (phototaxis) using antennas. Mandibles are used to filter water and phytoplankton.

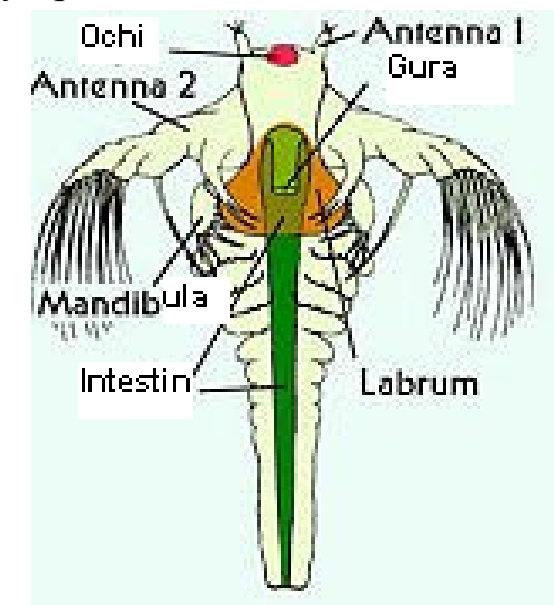

Figure 6. Anatomical characteristics of nauplia of Artemia salina 


\section{$\Rightarrow \quad$ Adults}

Adults swim using swim / filter feeding appendages. Median eye is accompanied by two lateral compound eyes. A simple brain formed a ring like structure around the mouth (typical of most invertebrates). Females develop eggs in a ventral egg sac with a rapid rate under favorable conditions.

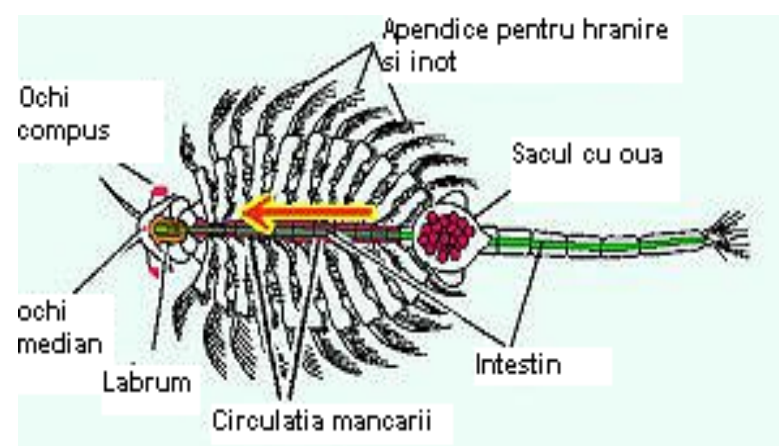

Figure 7. Anatomical characteristics of Artemia salina adult

\section{Importance}

Artemia salina species individuals, especially in stage nauplia, are used in aquaculture as live food for commercial growth (in incubators) of many species of fish and shellfish.

Resilience of these animals makes them ideal for testing samples in the experiments. Artemia salina is one of the organisms used regularly for toxicity testing of various chemicals.

Together with other bodies formed by decomposition salt lake bottom mud used to treat various rheumatic , gynecological, endocrine diseases, etc.

Salt water and mud from lake Ursu heliothermal contain hormones released by Artemia salina: human estrogen-like SU 95\%, respectively human progesterone-like 0.7 to 0.8 mg\% (Stoicescu Munteanu, 1977). They are used to treat gynecological diseases: ovarian failure, infertility, etc.

\section{References}

1. ABATZOPOLULOS T., BEARDMORE J., CLEGG J. and SORGELOOS P. (2010). Artemia. Basic and applied biology. Kluwer Academic Publishers.

2. ASEM A., RASTEGAR-POUYANI N. and RIOS-ESCALANTE P. (2010). The genus Artemia Leach, 1819 (Crustacea: Branchiopoda). I. True and false taxonomical descriptions. Lat. Am. J. Aquat. Res. v.38 n.3

3. CROGHAN C. (1957). The osmotic and ionic regulation of Artemia salina (L.). Department of Zoology, University of Cambridge.

4. MUÑOZ J., GÓMEZ A., GREEN A., FIGUEROLA J., AMAT F. and RICO C. (2008). Phylogeography and local endemism of the native Mediterranean brine shrimp Artemia salina (Branchiopoda: Anostraca). Molecular Ecology 17, 3160-3177.

5. STOICESCU C. and MUNTEANU L. (1977). Natural curative factors of the main balneoclimateric resorts in Romania. Edit. SportTurism, Bucharest.

6. VOS J. (1979). Brine shrimp (Artemia salina) inoculation in tropical salt ponds: a preliminary guide for use in Thailand. FAO Associate Expert (Culture of Food Organisms) National Freshwater Prawn Research and Training Center Freshwater Fisheries Division, Department of Fisheries Ministry of Agriculture and Cooperatives. Thailand.

7. VOS J. and de la ROSA NYMPHA. (1980). MANUAL ON ARTEMIA PRODUCTION IN SALT PONDS IN THE PHILIPPINES. FAO/UNDP-BFAR Brackishwater Aquaculture Demonstration and Training Project PHI/75/005

http://www.discoverlife.org/mp/20q? search=Artemia + salina http://www.artemiaworld.com/home/ http://jeb.biologists.org/content/35/1/219.full.pdf http://jgp.rupress.org/content/14/6/753.full.pdf http://www.drvoigt-consulting.de/background.htm http://www.isamm.org/artemia-salina.htm http://www.michaelsharris.com/12ubio/text/projects/brin eshrimplab.htm 


\section{Iodine waters}

\section{Munteanu Constantin ${ }^{1}$, Iliuta Alexandru ${ }^{2}$ ${ }^{1}$ Institutul Naţional de Recuperare, Medicina Fizica şi Balneoclimatologie ${ }^{2}$ S.C. BIOSAFETY SRL-D}

Iodine mineral waters are found especially in sub-Carpathian region, also in regions with Salif deposits. Waters are currently used iodine in drinking cure for chaps and Basedow. Are also indicated in balneology. Iodine water containing at least $1 \mathrm{mg} \backslash \mathrm{L}$, there is pure iodine is usually given the nature of other types of mineral waters further: sodium chlorinated water (Bazna $(50-70 \mathrm{mg}$ iodine / 1), Baile Govora (50 - $70 \mathrm{mg} / \mathrm{1}$ ), Bălțăteşti (4-5 mg / 1), salted Monteoru (30 mg / 1), mine) water mixed alkaline chlorination, sulphate, which are indicated for crenoterapie (hypo or isotonic to the bathrooms Olăneşti or Călimăneşti-Căciulata).

Iodine content of the water adds effects that broaden the indications for treatment. Iodine in water comes from sedimentary rocks and is home of former sea flora and fauna. Waters contain iodine and are used in internal treatment Olanesti meet in bathrooms (Sources: 5, 7, 8, 10, 11, 14, 19) and Călimăneşti to (6.8 Sources Pause) Cozia (1.3 Springs) . Abroad mineral iodine is at $\mathrm{Bad}$ Tolz, Bad Wiessee (Germany); Ciz, Luhacovice Lazne (CSR), Busko, (Poland), Bad Goisern (Austria); Salsomagiore, Castrocaro Agnano, Acircale, Salice (Italy). Groundwater salt concentration, iodine is found in high concentration (40-70 $\mathrm{mg} / 1)$.

Concentrated salt-iodine mineral water is used only in external cure. In crenoterapie intake of iodine in the thyroid contributes to its storage, as indicated in thyroid and ovarian endocrine disorders, which are adauaga and secretory stimulating effects on congestion and digestive mucosa. Although the amount of iodine is reduced by biological activity is remarkable.

Because of its ability to dilate blood vessels, thus facilitating movement chronically inflamed areas, facilitates the process of resorption and help improve local degenerative lesions. Moreover, it stimulated the body's defense capacity, thus improving the effective means of reducing the intensity of inflammatory processes. Also, through the direct intervention of iodine in improving cellular respiration, improves their resistance to aggression and inflammatory factors.

Due to the properties described, iodine waters are indicated for the treatment of chronic osteoarticular diseases, where the maximum effect is achieved by associating the internal hydro external cure. Iodine is present in low concentrations numerous mineral springs which are used in internal treatment. Ingested with mineral water, iodine exerts its farmacodina-small lymphoid tissue due to its concentration in the thyroid and liver.

The digestive mucosa congestion and stimulating exercise effect secretions. Thyroid function is particularly influenced by internal treatment with iodine mineral waters. Water treatment with iodine is shown in hipofuncții thyroid iodine deficient or iodine hipofunctii loss, and metabolic diseases with atherosclerosis, gout and hyperuricemia in.

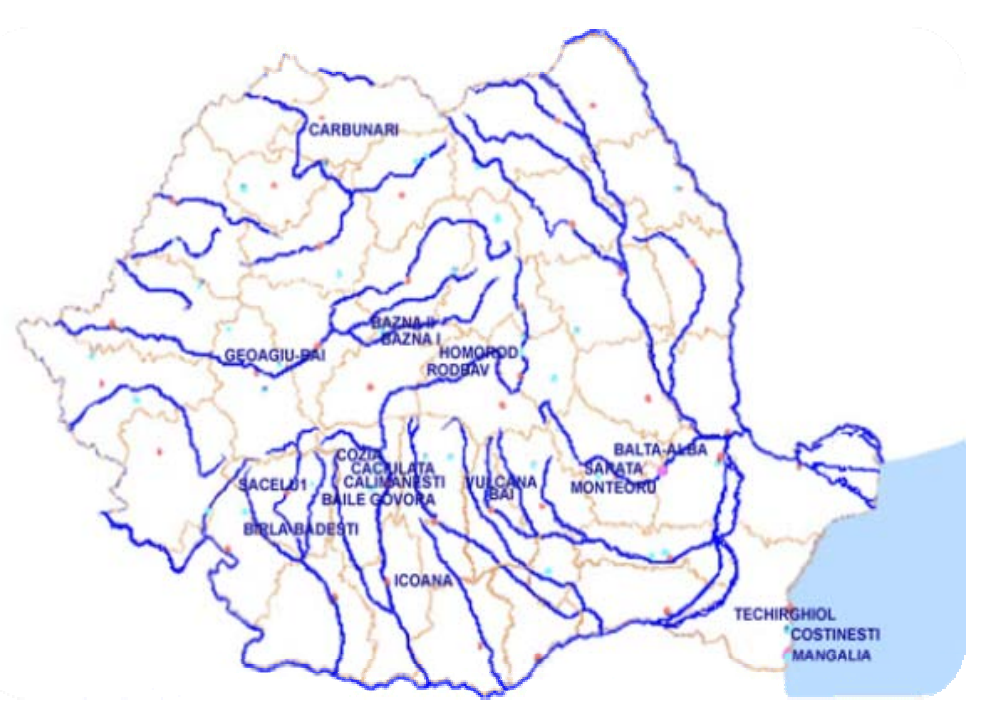


The external treatment (chlorinated bath water mixed sodium and iodine) iodule peripheral vasodilator effect antifungal effects in the skin and appendages.

Are indicated in patients with peripheral atherosclerosis or general, in patients with uric artitra and in patients with fungal skin disease. Salt-iodine baths are indicated in degenerative rheumatic diseases in rheumatism abarticulare or peripheral neurological diseases. By influencing metabolic reactions, clean hydromentioned is useful in the treatment of diseases such as gout and chronic poisoning with mercury and lead.

Also, by stimulating the uptake and degradation of cholesterol in arterial walls, iodine waters slow the progression of lesions ateroscle-pink. Mineral baths have a special contribution in improving the clinical manifestations of disease in that the rheumatism, circulatory, nervous, gynecological and dermatological. Iodine and other minerals contained in therapeutic bath are absorbed into the skin where they are gradually released into peripheral circulation.

On its obvious improvement occurs, due to dilatation of blood vessels deeper layers of skin and skeletal muscle neighborhood. By reducing resistance in these vessels an object thrown in front of the circulating blood volume with each cardiac contraction, blood pressure lowering is found environments.

However, there are indirect improvement of heart and vessel traffic cardiac oxygen consumption, parasitic skin affections (pityriasis verzicolor), mineral iodine has been effective in improving until complete healing of skin lesions. By stimulating local circulation and reduce inflammatory processes, iodine occurs in lower genital chronic congestive phenomena (prostatitis and chronic metroanexite). Also intervening in restoring cellular structures and to improve nerve management, hydro-iodine diet facilitates peripheral nervous system tone affected by certain chronic diseases. Rheumatic diseases also benefit from the therapeutic effects of iodine baths. The most famous resorts where you can practice these baths are: Vulcan Govora Bazna, Sarata-Monteoru, CalimanestiCăciulata.

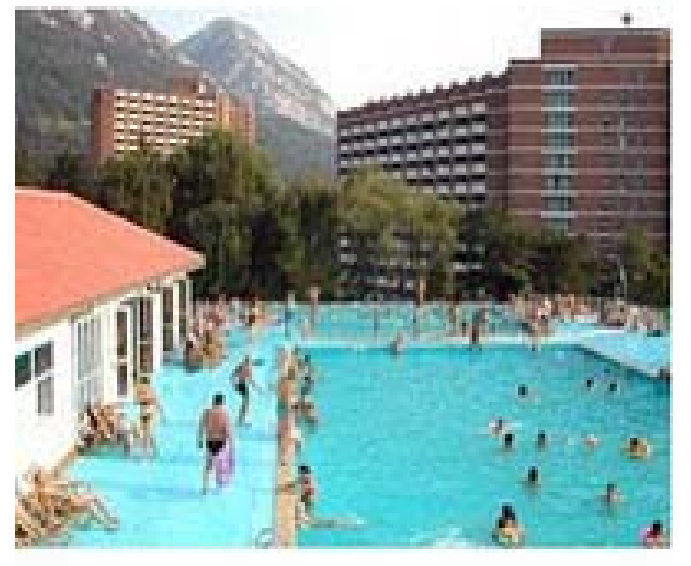

State with iodide Mineral Complex (for internal cures): Baile Olanesti CalimanestiCaciulata, Carei;

State with iodide Mineral Salt (for external cures): Baile Govora Bazna, Baltatesti, Sacelu, Salt Monteoru, horseshoes, mine;

\section{Olanesti Bai}

Geographic area: Skull Mountains - Valcea Subcarpatii

Type area: mountain basin / river / spring: the confluence of the Tisza Olanesti

Location: Mv. Wind and stack (N) - Cut Stone Hills (919m alt), Glod (NV), Tisa (V), Budestii (SV), Plaiul Miron (E)

\section{Conditions:}

- Digestive (hypoacid chronic gastritis, chronic constipation, chronic colitis)

- hepatobiliary (biliary dyskinesia, chronic cholecystitis not calculated or computer, disorders after liver surgery, chronic hepatitis, chronic pancreatitis)

- respiratory (respiratory dry climbing, people exposed to noxious professional people with common microbial or viral pneumopathies, allergic asthma, chronic bronchitis and traheobronsitele, bronchiectasis)

- Metabolic and nutrition disorders (diabetes mellitus, hyperuricaemia states of hiperlipezii, obesity)

- ENT diseases (chronic laryngitis, allergies naso-sinus)

- dermatology (psoriasis, ichtioze early, keratodermii, eczema and chronic hives, 
neurodermatitis, seborrheic dermatitis, acne, pyoderma) and degenerative

- rheumatic abarticulare

- neurasthenia accompanied by insomnia

- recovering from acute and chronic infectious diseases internal treatment: to cure inner-springs are given $3,5,7,8,9,10,11,12$, $14,19,24$ in-chronic stomach and intestine, chronic liver disease and kidney disease, biliary and urinary tract, skin diseases.

Internal cure:

-for internal cure are indicated springs 3,5 , $7,8,9,10,11,12,14,19,24$ in

-chronic stomach and bowel, and chronic liver disease, biliary diseases kidney and urinary tract, skin diseases.

\section{Calimanesti-Caciulata}

Geographic area: Skull Mountain, Cozia Type

area: mountain

basin / river / stream: Olt, spring out of the rocks Caciulata Pisorea Hill Location: Plaiul Frasinet (another 999m) Pisorea Deal

\section{Conditions:}

- external cure diseases of the digestive tract associated with musculoskeletal disorders, the cardiovascular system (hypertonic disease with maximum up to $17-18 \mathrm{~cm}$ ), peripheral circulation disorders, gynecological

- diseases of the digestive tract (hypoacid chronic gastritis, chronic constipation, chronic colitis)

- - hepatobiliary (biliary dyskinesia, chronic cholecystitis not calculated or computer, liver disorders after surgery (cholecystectomy), chronic hepatitis, chronic pancreatitis))

- Renal and urinary urinary (or unoperated renalaoperata stones, urinary stones, chronic pyelonephritis, urinary infections, chronic glomerulonephritis stabilized)

- Metabolism and nutrition (diabetes mellitus, hyperuricaemia states of hiperlipemii, obesity)

- rheumatic degenerative (cervical, dorsal, lumbar arthrosis, poliarthrosis)

- rheumatic inflammatory (allergic states joints after acute articular rheumatism or infections after outbreak)

- rheumatic abarticulare (tendinosis, tendomioze, tendoperiostoze, scapulohumeral periarthritis)

- traumatic (post-traumatic joint redori, states after operations on muscles, bones and joints, states as sprains, dislocations and fractures)

- $\quad$ peripheral neurological (paresis, states after polio)

- respiratory (breathing people exposed to pollutants, microbial or viral, allergic asthma, bronchitis and chronic tracheobronchitis, bronchiectasis)

- associated

(gynecology, otorhinolaryngology, dermatology, cardiovascular, endocrine, asthenic neurosis, diseases)

- Sulphur baths, carbonic acid baths and artificial bubble. 


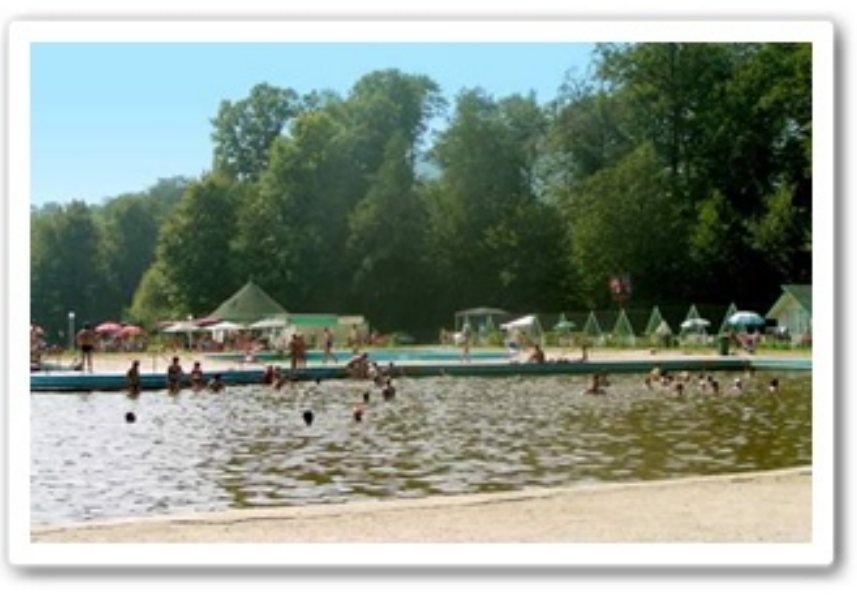

Băile Govora

http://www.bailegovora.ro

Geographic area: Subcarpatii Valcea area

Type: hill

basin / river / stream: Swing

Location: between hills Piscupia $(\mathrm{N})$, fried $(\mathrm{N})$, Frasinet (S), Curaturile (S), Zapodul (S), Bodeanca (E)

External cure:

-musculoskeletal disorders, endocrine hypofunction, gynecological, with peripheral and central nervous system (light paresis and minor sequelae after polyneuropathies, sequelae after poliomyelitis sequelae late after parapareze hemiparesis after 2 years of onset), dermatology ( chlorine sulphurous waters), peripheral circulatory disorders, chronic ganglion (iodine chlorine water), chronic poisoning with mercury, arsenic, bismuth

-respiratory (rhinitis, pharyngitis, laryngitis, bronchitis with hiposecretie (iodine), with hypersecretion (sulfur) in which case water is diluted to lower concentrations irritating before, people exposed to respiratory hazards, people with common

-microbial or viral pneumopathies, allergic asthma, chronic traheobronsitele, bronchiectasis, scleroenfizemul lung), otorhinolaryngology (catarrhal and chronic rhinosinusitis with effusion), rheumatic degenerative (cervical, dorsal, lumbar arthrosis, poliarthrosis)

-rheumatic abarticulare (tendinosis, tendomioze, tendoperiostoze, scapulohumeral periarthritis), posttraumatic (posttraumatic joint redori, states after operations the muscles, joints and bones, state after twists, sprains, fractures)-associated (gynecological, endocrine, cardiovascular diseases).

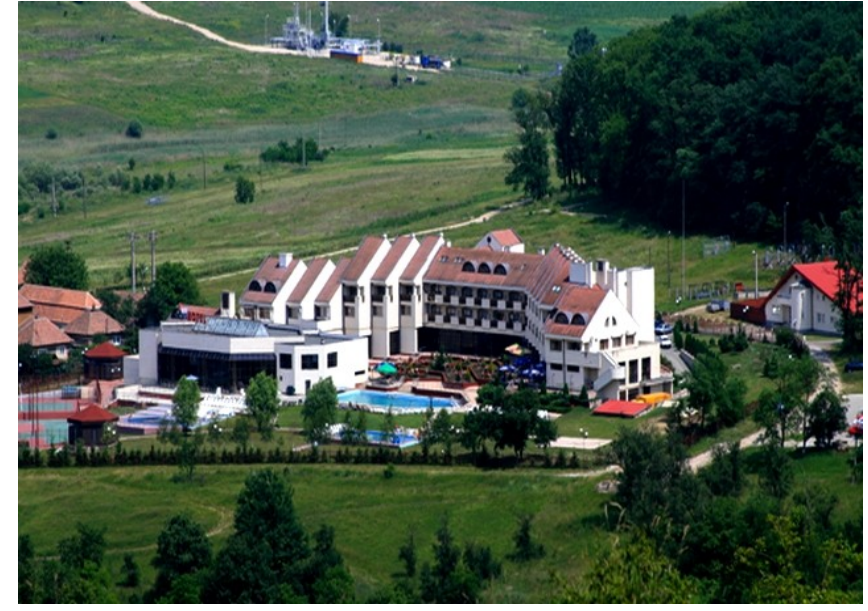

\section{Băile Bazna}

http://www.skytrip.ro

Geographic area: Small Type Tarnava Hills area: hill

basin / river / stream: Bazna

Location: High Hill (599m alt)

\section{External cure:}

-mineral baths and mud procedures for degenerative rheumatic diseases (cervical, dorsal, lumbar arthrosis, poliarthrosis)

-rheumatic inflammatory (allergic state after rheumatic fever or infection after the outbreak), rheumatic abarticulare (tendinosis, tendomioze, tendoperiostoze, scapulohumeral periarthritis

-traumatic (post-traumatic joint redori, states after operations on the joints, muscles and bones, state after twists, sprains and fractures), chronic musculoskeletal disorders (chronic arthritis, spondylitis, arthritis traumatic, painful calluses)

- chronic dermatological (skin disease), peripheral nervous system (state of fatigue, paralysis, traumatic paralysis, sequels after polyneuropathies, sequelae after poliomyelitis poliradiculoneuropatii), endocrine and nutrition (debility in children, rickets), exudative diathesis

-cure king's evil foreign

-vaginal irrigation with warm salt water (38 C - 40 C) for chronic gynecological (ovarian insufficiency, cervicitis, chronic metroanexite)

\section{References}

http://articole.famouswhy.ro/

http://www.inffo.ro

http://e-calauza.ro 


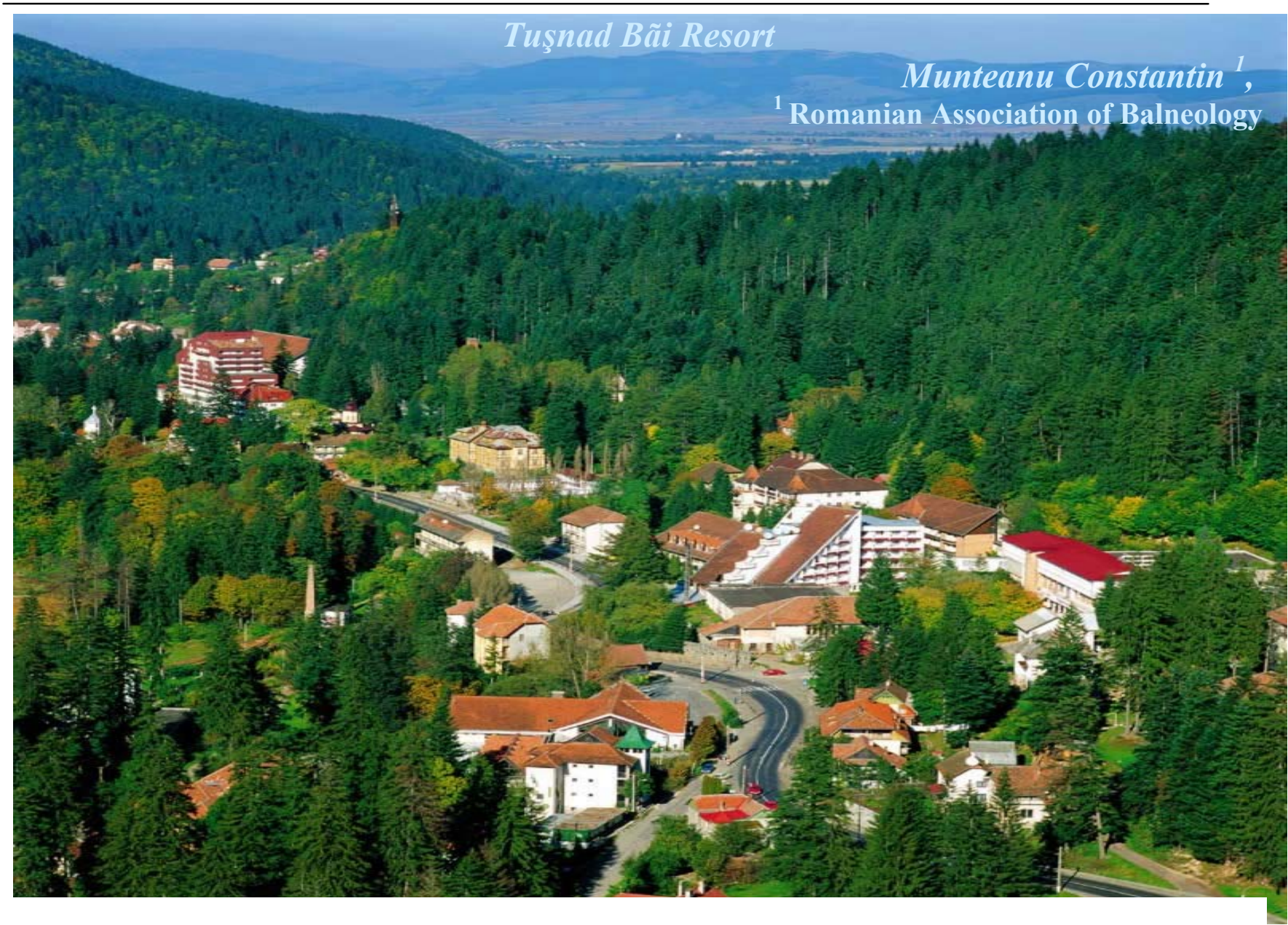

Geographical situation: The village is situated in the central-eastern Romania (Harghita county), Olt River in extreme southern part of Ciuc Depression, altitude $656 \mathrm{~m}, 32 \mathrm{~km}$ south of Miercurea Ciuc. Quay Malnas- Tusnad of Olt, the air highly ozoned, the peace, the comfort and treatment of with mineral waters Tusnad Bath have made of a fine resort and an ideal place for holidays in any season. City has a subalpine climate, of mountain valley, with cool summers (July average temperature is 17.5 ${ }^{\circ} \mathrm{C}$ ) and cold winters (average temperature in January is $-7^{\circ} \mathrm{C}$ ). Moderate rainfall (between 600 and $700 \mathrm{~mm}$ annually). Mountains shield against the wind.

Natural therapeutic factors: All-season resort, with numerous springs (known since the early nineteenth century, but only since 1860): bicarbonate mineral, carbonated, chlorided, sodic, magnesian, ferruginous, calcic and mesothermal waters used in an outdoor pool.

Therapeutical indications: The resort is recommended for the treatment of central nervous system (asthenic neurosis, secondary asthenic conditions, stress, physical and intellectual), cardiovascular (myocardial infarction, hypertension, peripheral arterial disease, postflebite states, varicose veins), urinary system diseases (kidney stones, inflammation ) and related diseases (digestive, endocrine, gynecological, etc.). Modern treatment facilities: baths with carbonated mineral waters, galvanic baths, parafin packing, electrotherapy equipment, gyms, pits (natural emanations of carbon dioxide) with room for carbon dioxide inhalations.

Three hours walking distance of St. Ana Lake - the only volcanic lake in Romania, at an altitude of $950 \mathrm{~m}$. 
Vol.2, Nr.4, 2011

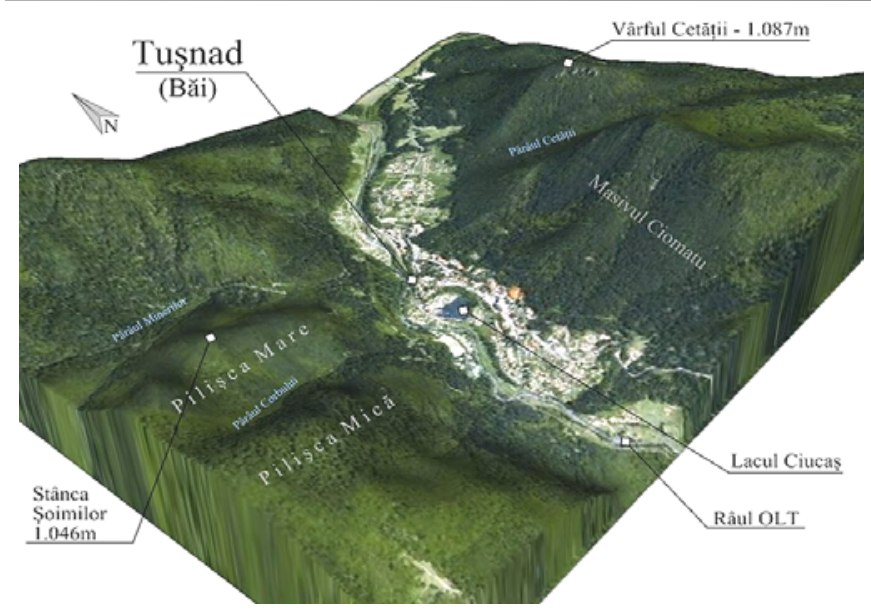

NATURAL CURATIVE FACTORS:

Tusnad Bai balneo-climateric resort has a wide range of therapeutic factors that led to the formation of one of the most popular areas of both physical and psychological recovery in Romania. Among these factors therapeutical mineral water you can find different chemical composition (chloride, sodium, bicarbonate, pits), equipment and aerosol inhalations, electrotherapy, therapeutic masajuri, hydrotherapy and last but not least, a tonic type bioclimate sub strong air ozonized.

\section{ACCESSIBILITY}

Road: Braşov - Sf. Gheorghe -Tuşnad Băi Miercurea Ciuc DN 1267 km from Brasov, 37 $\mathrm{km}$ from St. George, $32 \mathrm{~km}$ from Miercurea Ciuc; Bacău - Comăneşti - Miercurea Ciuc DN 12A.

Rail: Magistrala Bucureşti - Braşov - Sf. Gheorghe -Tuşnad Băi - Ciceu - Deda - Baia Mare, station Tuşnad Băi.

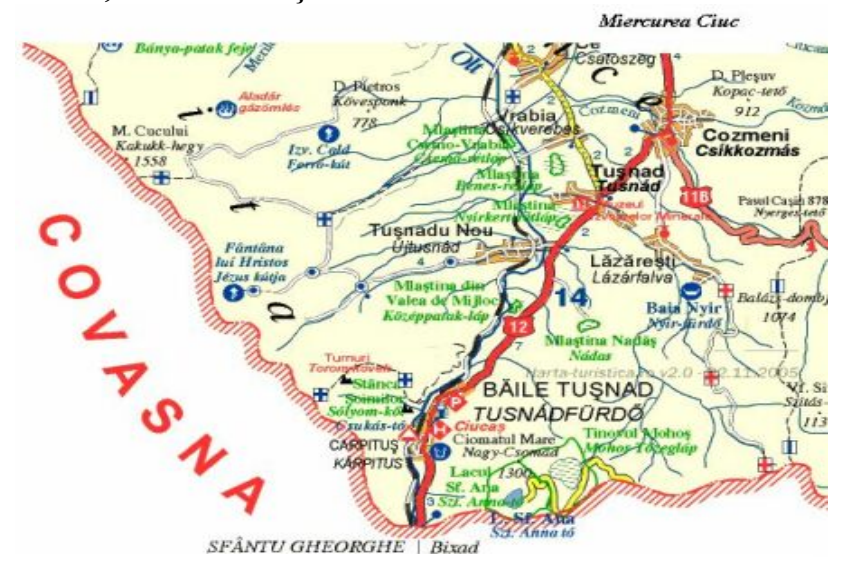

CLIMATE. Surrounded by secular pinewoods, the resort has clean air, ozonized, rich in aerosols and negative ions and an alpine climate. The average annual temperature is $8^{\circ}$ $\mathrm{C}$ (July $17.5^{\circ} \mathrm{C}$, January $7^{\circ} \mathrm{C}$ ) and cold winters, low cloudiness.
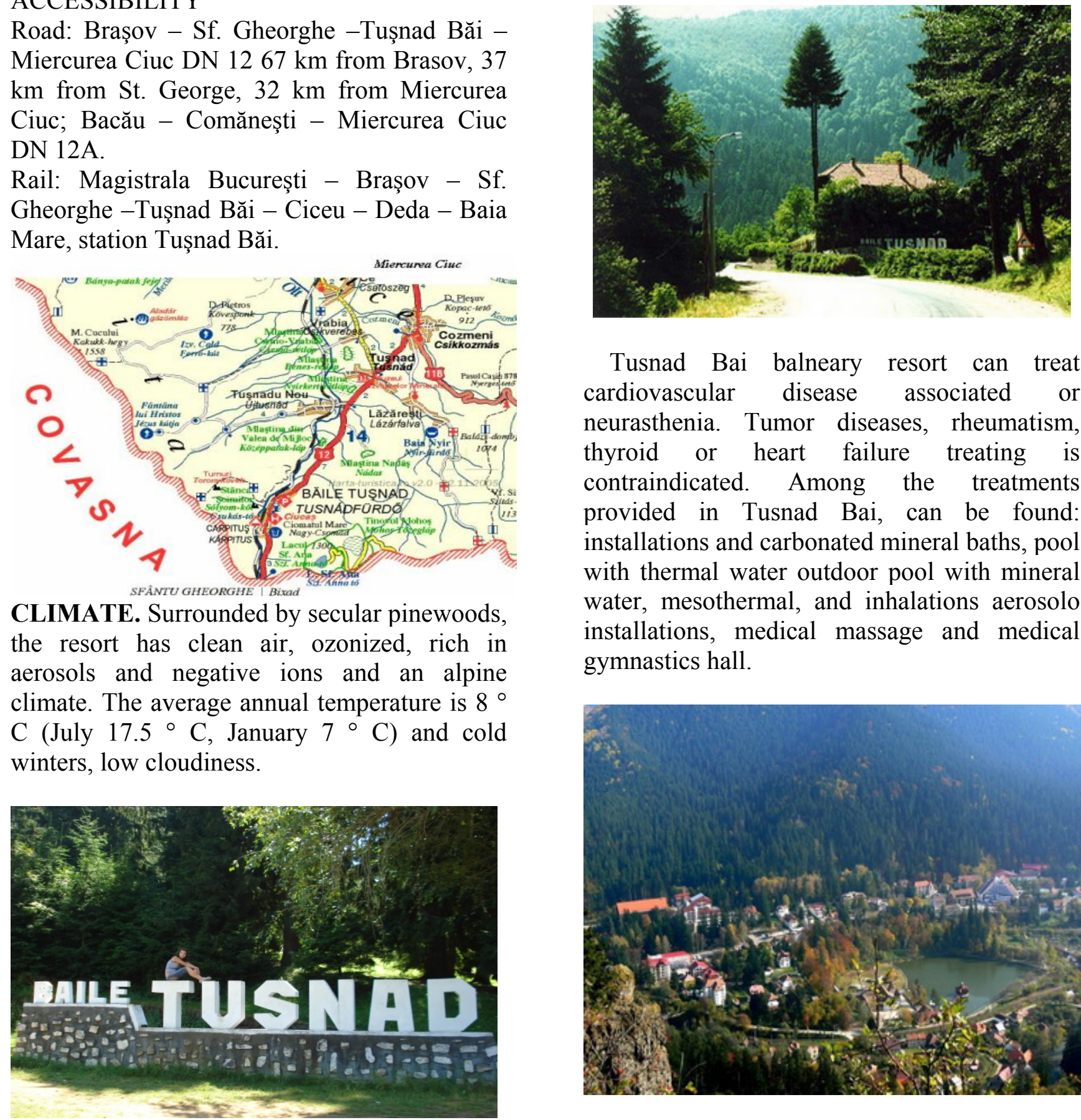

Tusnad Bai balneary resort can treat cardiovascular disease associated or neurasthenia. Tumor diseases, rheumatism, thyroid or heart failure treating is contraindicated. Among the treatments provided in Tusnad Bai, can be found: installations and carbonated mineral baths, pool with thermal water outdoor pool with mineral water, mesothermal, and inhalations aerosolo installations, medical massage and medical gymnastics hall.

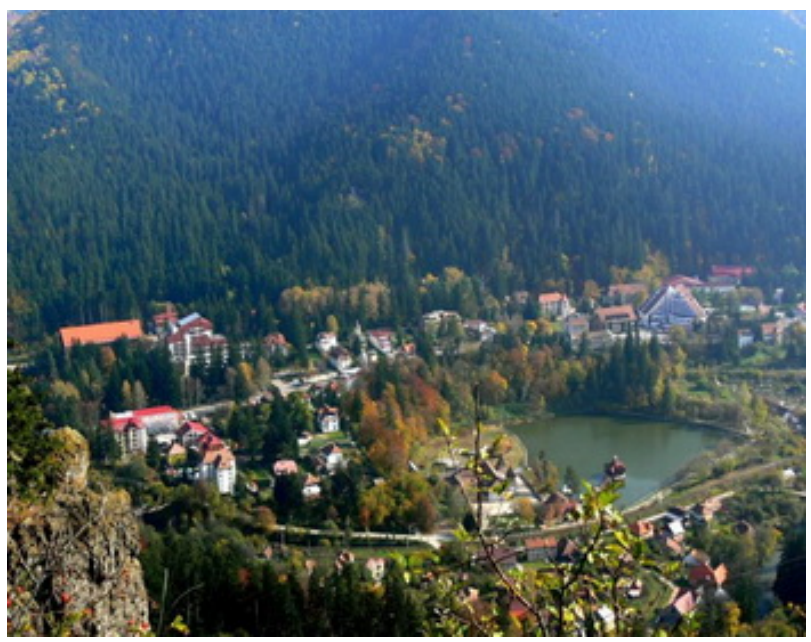




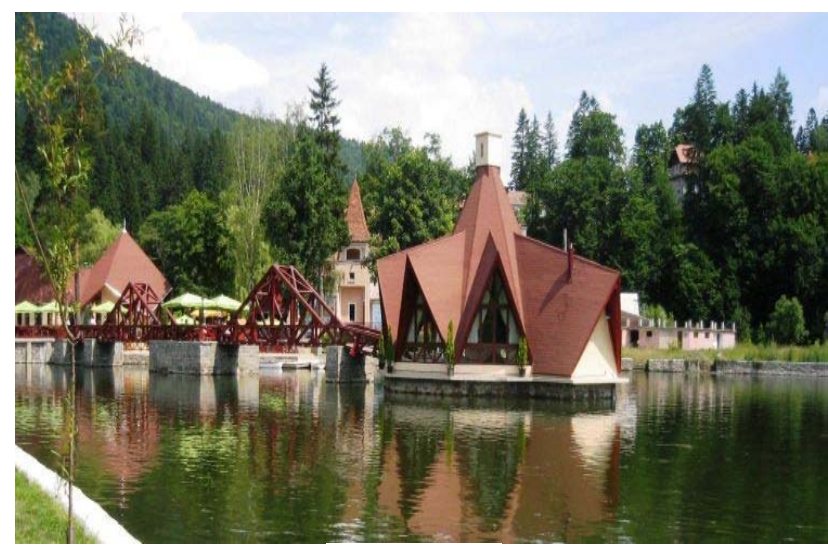

Tusnad Băi

About Tusnad mineral waters there written evidence since the eighteenth century, mentioning the existence of springs with curative effects used by locals nearby villages.

This resort with various springs, mesothermal and pits is recommended for the treatment of cardiovascular, urinary and nervous system. There are 44 natural springs and wells which are currently used six natural springs, of which four (Izv. Stanescu, Apor, Ileana and Mikes) for external cure. By internal cure can treat digestive diseases, hypoacid gastritis, chronic cholecystitis and hepato-, neuro endocrine and metabolic diseases.

By external cure, baths are recommended in cardiovascular disease, impaired circulation, rheumatic and asthenic neurosis or strain, musculoskeletal diseases.

The resort is equipped with treatment base, which is made carbonated baths warm paraffin applications, hydrotherapy and physiotherapy, medical gymnastics, electrotherapy. The complex is equipped with 40 valves and can cure 800 patients per day. Outdoor pool is fed by the waters of Spring Baths.

\section{History}

The therapeutic effect of thermal water from Tusnad Bai balneo-climateric resort has attracted the attention the public for the first time in 1842 after the miraculous healing of a son of a shepherd. Company stock in order to exploit the resort was established in 1845.

After the revolution from 1849, Tusnad Bai resort was destroyed and rebuilt in 1852.
Tusnad Bath assumed name-only in 1861 and was decalrat city in 1968. The first written evidence about the thermal waters of Tusnad Bai appear stating with the eighteenth century existence when it mention the existence of mineral waters springs with therapeutic effect.

In 1866, chemist H. Dietrich Gustaw is the first analysis of thermal waters of the eight main springs of balneary resort Tusnad Bai. Main source of water pouring begins in the same year. Follow the construction of the swimming pool mesothermal on the main spring water.

In 1875, Dr. balneologist Lengyel Gyula presents the history and values of the resort spas spa Tusnad Bath the Hungarian national conference of physicians naturalists. This event was one of great importance for Tusnad Bath. The golden age of the resort begins with 1880 . Under the tutelage of Stefania Balnear Institute, an important institution at the time balneary, the resort is endowed with four indoor, four cold baths, and 14 personnel porcelain tubs.

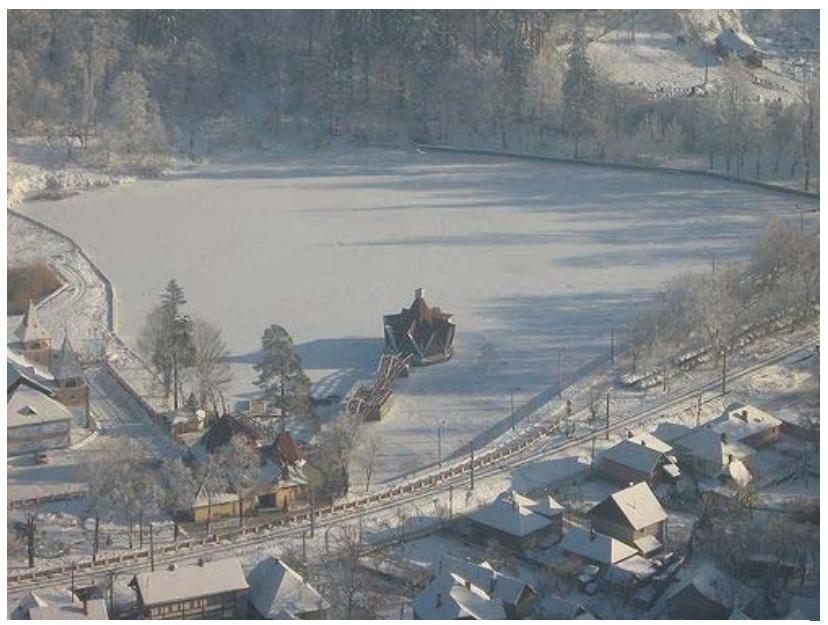

Tusnad Bai

The first balneary clinic occurs between 18961897, but was destroyed in 1913 in a fire. The First World War brought the end of the golden age of Bai Tusnad, who was noted for at that moment as the Pearl of Transylvania. At the end of The First World War, the balneoclimateric resorts started back, that by 1927 to be recognized internationally as the leading balneo-climateric resorts.

In 1973 the first Balneary company is formed whose headquarters is moved in 1985 to Miercurea Ciuc. In the same period is introduced electricity, sewerage and are 
drinking water network built. Tusnad Bai thermal swimming pool was created as a result of drilling at depths of 1100 meters where he found the thermal water of 63 degrees Celsius.

Since 1995, Balneoclimateric resort Tusnad Bai becomes once again an international conference center and the effort to raising the Tusnad Bai to former glory continue to date.

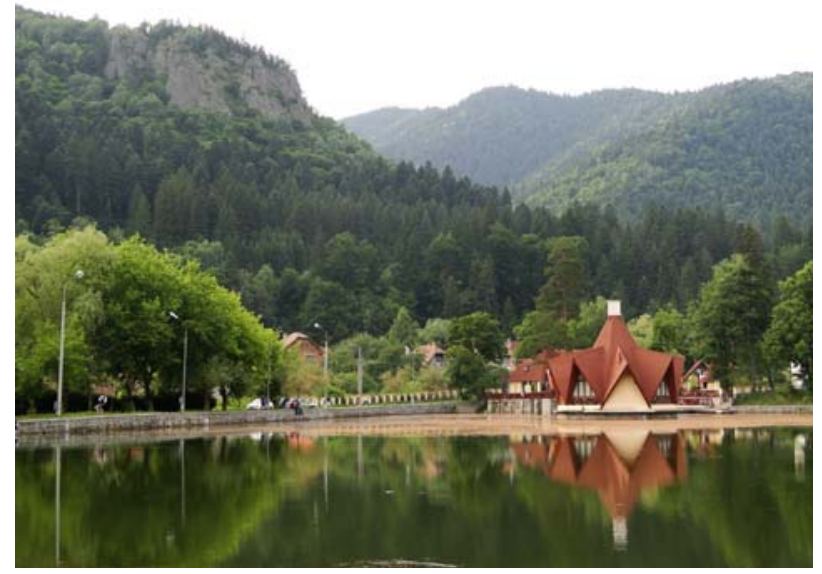

\section{Tusnad Bai attractions.}

- The Bicaz Quay is one of the most popular tourist locations in Romania.

- The Soimi Cliff (the Hawk's Cliff), an andesite formation offers a view of the Olt defile and mountain peaks of the area and is the home of Cliff Soimi fortress ruins.

- Saint Ana Lake is a lake with volcanic origin situated at 950 meters high and $25 \mathrm{~km}$ from the Tusnad Bai balneary resort.

- Mohos Tinov is a natural reservation located near the Saint Ana Lake that shelters rare species of plants.

- Odorheiul Secuiesc is a medieval city from the sixteenth century.

- Orthodox Monastery "St. Prophet Elijah" in Toplita monastery built in 1847 .

- " Tartars Movila " and the castle of Count Lazar from Lazarea.

- Baroque Franciscan church Sumuleu has one of the biggest harmonium installations in Transylvania.
Mineral waters, abstracted from the natural sources, the gases healing considered rarities of nature even in Europe, salt lakes, mud and peat therapeutic and medicinal plants rare climatic factors gives Tusnad a status of exceptional balneary resorts.

Volcanic rocks of Harghita mountains consist andesite and limestone deposits have occurred due to the effects of various mineral waters. This explains the diverse composition of the water.

Tusnad own volcanic formations have played an important role in the development of the balneary resort. Emanations of carbonic acid and more than 48 mineral springs with temperatures between 18 and 24 degrees Celsius, can be used in internal and external cures

The small balneo-climateric resort from Romania is famous for its unique landscapes and healing springs. Tuşnad was the place where, a century ago, was attracted elite of Europe.

Tusnad surroundings shelter the cleanest lake in the world, the only carnivorous plant in the country and the largest mofetta in the world.

Harghita and Bodoc Mountains shelter Tusnad, the smallest resort in the country. "The Pearl of Transylvania" or "Little Switzerland" was famous by its mofettes, healing gas which cross the cracks of earth.

From the mountains of volcanic origin, which only Olt waters succeed to squeeze, spring out natural springs, which began to be exploited in 1860, and subalpine climate and unique landscapes he encountered here relax and delight tourists come from hundreds or even thousands of miles away.

From the city of St. George, from Bixad village, the road to where legend says that the water was healed by the miracle of a son of a shepherd, is hidden among pine forests and lead to villas, once chic, many of them built since the century the nineteenth century. 


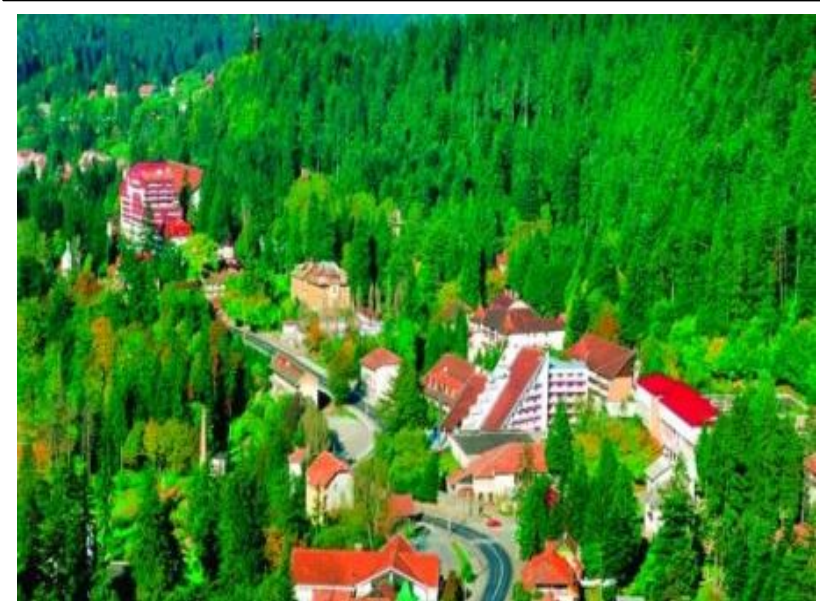

\section{Disappeared natural monuments}

At 650 meters altitude, clean air quickly erase any trace of fatigue. Tusnad Bai, a scattered small town on both sides of the Olt, whirling the dried branches and rubbish have been documented in Romanian in 1861, and in 1880 started the golden age of the resort.

In 1890 the balneary institute Stephanie is established, famous at that time, worldwide, equipped with indoor swimming pools, with porcelain tubs and personnel in balneary medicine. World War brings end the golden age of the resort, but due to its reputation and beneficial qualities of healing springs in 1927, Tusnad regain fame.

In 1980, with the deviation Olt, were destroyed many of the beauties of these places. Likasko rock formations, a natural monument no longer exists, and since 1989 has been left derelict old villas which housed both tourists and hot springs.

\section{Miraculous mineral waters}

Bottled mineral water to Tuşnad, passes through layers of limestone that are protected by an impermeable layer of volcanic lava. The natural process of filtration and mineral enrichment takes thousands of years.

Tuşnad Mineral Water treatment is limited to removal of iron content and is an ultra-modern station.

Mineral waters, abstracted from natural sources, gas mofette considered rarities of nature even in Europe, salt lakes, mud and peat therapeutic and medicinal plants rare climatic factors gives Tusnad a status of exceptional balneary resorts.

Volcanic rocks of Harghita mountains consist andesite and limestone deposits have occurred due to the effects of various mineral waters. This explains the diverse composition of the water. diferitelor ape minerale.

Tusnad own volcanic formations have played an important role in the development of balneary resort. Emanations of carbonic acid, mofettes, more than 48 mineral springs with temperatures between 18-24 degrees Celsius, can be used in internal and external cures.

\section{Hawk's Cliff}

Any tourist who comes in Tuşnad wants to conquer the Hawk's Cliff) who, from a height of 824 meters, offers a rare view of the entire defile of Olt. The paths to the cliff start from Tusnad Bai resort and are marked for tourists with "red triangle" and go pretty hard to top of andesite, which is built a wooden cross.

Children and elders alike, venturing on the strain paths among trees on the Hawk's Cliff, which has a status of nature reservation.

Tuşnad city has $\mathbf{1 . 7 2 8}$ of inhabitants; is located in the southern part of Ciuc Depression

\section{The only carnivorous plant in Romania}

"The Dew of Sky" is the only carnivorous plant in Romania and flourishes very rarely in Mohos Tinov, in the southernmost point of vegetation in the world. "The Dew of Sky" is in this place, which is its natural habitat, of 12,000 years and feeds on insects 20 times higher than it.

She attracts the victims with two tentacles found on the petals which shining drops poisonous sap. Surrounding them and then dissolved in them until there were only skeleton made of chitin. Species of plants and insects that live in Mohos Tinov received from the European Union the title of unique.

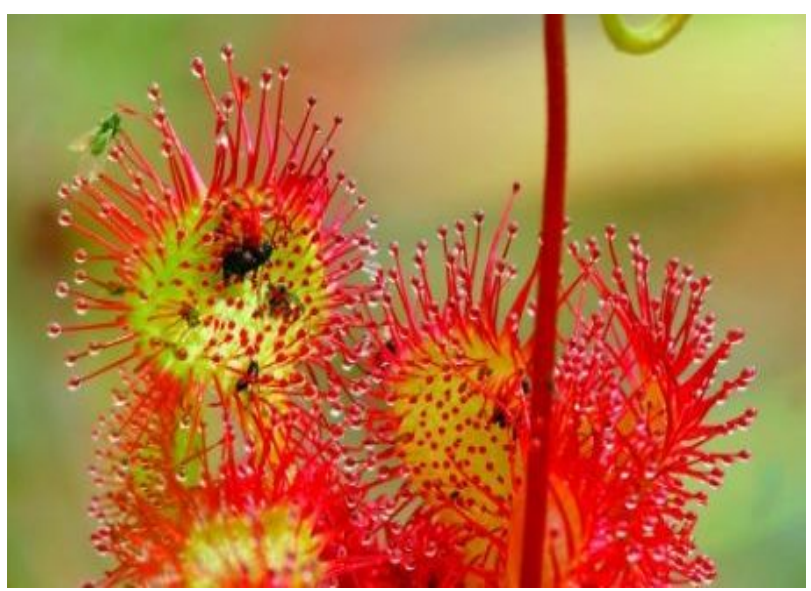

Drosera rotundifolia 


\section{Saint Anne Lake, the cleanest lake in the world}

Unique in Central Europe, Lake Saint Anne located at an altitude of 946 meters and 28 kilometers from Tusnad Bai. Formed in an extinct volcanic crater, which has been preserved intact in the massive Puciosu, in the Ciumatu Great mountains, where the most recent volcanic eruptions in the Carpathians, which took place about 42,000 years ago.

Like a painter palette, the lake waters only gathers by rainfall, with no springs. Lake water, due to lack of mineral salts, is not potable and is devoid of oxygen. The lake is linked to Tusnad Bai by paths; was declared a nature reservation, is hidden eyes, mysterious and full of legends.

The experts tell that purity water of Saint Anne Lake is close to that of distilled water, with trace amounts of minerals. Tourists arriving in the lake do not need to learn weather forecast weather. They have at hand an empirical method, but accurate, given the volcanic mountain that has two cracks that predict weather.

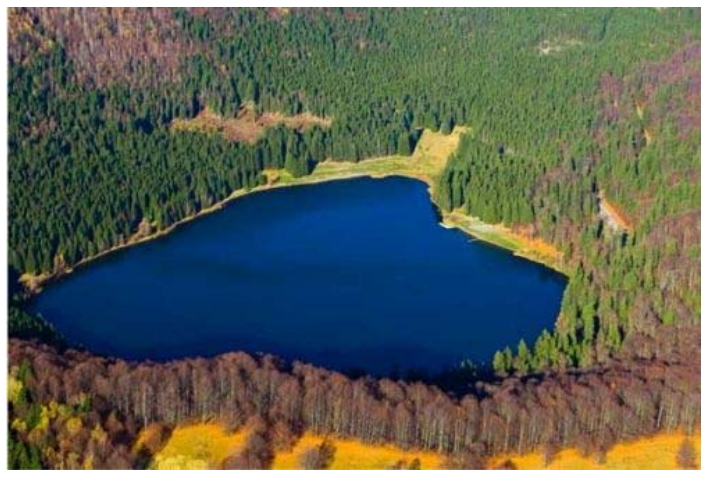

\section{Mohos Tinov- natural rezervation}

If the emanations from cracks irritating the nose, is a sign that the storm will start and if they do not feel, hiking can be sure that the weather will be beautiful.

Scientific explanation of the phenomenon consists in the fact that there is still a mountain activity postvulcanic, sensitive to changes in atmospheric pressure. When the pressure decreases, gases inside rises to the surface and fills cracks with a pungent odor.

Tinov Mohos natural reservation is adjacent to the crater of Saint Anne Lake and hosts rare plant species.

In Mohos Tinov can be found over 20 varieties of moss, and dwarf pine bonsai resemble amazing Japanese. Tinovul peat layer of a thickness of ten feet, is considered the thickest in Europe and is constantly growing.

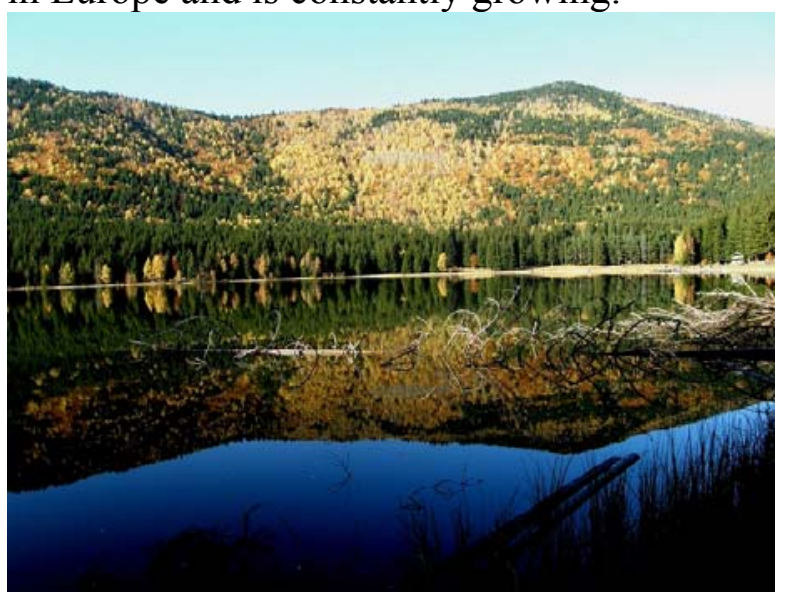

\section{The biggest of the world mofetta}

Therapeutic qualities of the numerous mineral springs and of mofettes from Balvanyos balneo-climateric resort, near Tusnad, located at an altitude of 950 meters on the southern slope of the mountains Bodoc are famous.

The silence of the mountains, fresh air, rich in negative ions Balvanyos make an ideal place for those suffering from fatigue or want to escape, at least for a time of stress. The resort was formed by merging three baths colonies, of which the best known is Pucioasa, whose name comes from the smell you give off hydrogen sulfide.

Pucioasa Cave is considered the world's largest natural mofetta. Cave walls are covered with drops containing sulfur and is used in ophthalmologic diseases. Another curiosity of Balvanyos natural balneo-climateric resort is Buffago a bog that stretches over one hectare and where springs and rare plant species can be found sour.

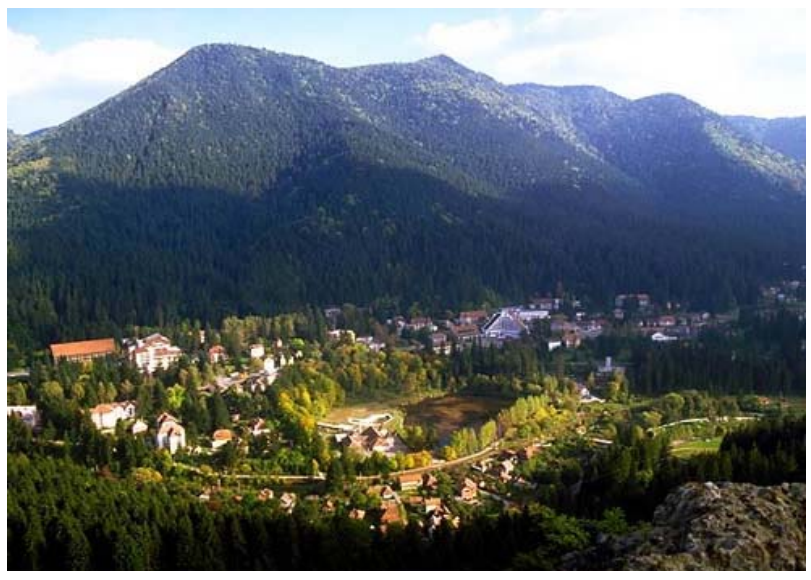

http://www.experience-romania.ro/Baile_Tusnad 


\section{AGENDA}

\begin{tabular}{|c|c|}
\hline & $\begin{array}{l}\text { The X National Conference of Balneology, } \\
\text { May 2012, SOVATA } \\
\text { Details will be published on the website of the Romanian Association of Balneology: } \\
\text { http://bioclima.ro/ }\end{array}$ \\
\hline \multirow[t]{2}{*}{$\frac{1 \text { ism }}{5}$} & $\begin{array}{l}\text { 38th World Congress of ISMH, the International Scientific Meeting of Medical } \\
\text { Hydrology Balneology and Climatology, will take place in Lanjarón-Granada Spain, } \\
\text { 20-23 June 2012. }\end{array}$ \\
\hline & $\begin{array}{l}\therefore \text { FENS Forum } 2012 \text { in Barcelona } \\
\text { July 14-18, } 2012 \\
206 \text { days left till the meeting } \\
\text { Please visit the next FENS Forum in 2012! }\end{array}$ \\
\hline $1 / \mathrm{H}$ & $\begin{array}{l}\text { BALWOIS } 2012 \text { - } 28 \text { May to } 2 \text { June } 2012 \text { - Ohrid, Republic of Macedonia } \\
\text { The Fifth International Scientific Conference BALWOIS } 2012 \text { will be held in Ohrid, Republic of } \\
\text { Macedonia from 28th May to 2nd June 2012, in Metropol Ohrid Resort www.metropol-ohrid.com. } \\
\text { ABSTRACT:Constantin Munteanu, Delia Cinteza - Romanian therapeutical mineral waters }\end{array}$ \\
\hline \multirow[t]{2}{*}{ 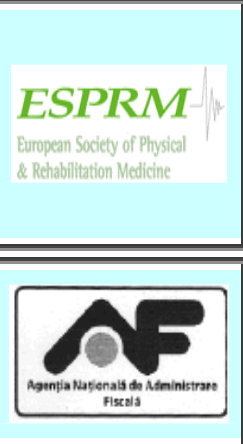 } & $\begin{array}{l}\text { Al 18-lea Congres al Societatii Europene de Medicina Fizica si de Recuperare } \\
\text { (ESPRM) } \\
\text { 18th European Congress of Physical \& Rehabilitation Medicine "Science \& Art in Physical \& } \\
\text { Rehabilitation Medicine", Macedonia Palace Hotel, Thessaloniki, Greece, Dates: 28th May - 01st } \\
\text { June } 2012\end{array}$ \\
\hline & $\begin{array}{l}\text { NGO status of the Romanian Association of Balneology, objectives and willingness of industry to get } \\
\text { involved in our approach is also possible by completing and submitting the Tax Administration's } \\
\text { home form } 230 \text { that you can download and complete. Thank you for your effort and desire to be with } \\
\text { us. }\end{array}$ \\
\hline & $\begin{array}{l}\text { Balneo-Research Journal, Vol. } 3 \\
\text { web: http://bioclima.ro/RJournal.htm } \\
\text { Interested authors can submit articles to: secretar@bioclima.ro }\end{array}$ \\
\hline$\overline{-}-$ & $\begin{array}{l}\text { Balneara Publisher: } \\
\text { Cercetarea stiintifica a factorilor naturali terapeutici } \\
\text { Autori: Constantin Munteanu, Delia Cinteza } \\
\text { Commands: } \underline{\text { secretar@bioclima.ro }}\end{array}$ \\
\hline \multirow{3}{*}{$\begin{array}{c}\text { Romanian } \\
\text { Association of } \\
\text { Balneology INR } \\
\text { MFB } \\
\text { organizes the } \\
\text { following } \\
\text { courses: }\end{array}$} & "Technician ortoprotezist" - CNFPA approved course \\
\hline & $\begin{array}{l}\text { "Technician ecology and environmental quality protection "- CNFPA approved } \\
\text { course }\end{array}$ \\
\hline & $\begin{array}{l}\text { Other specialized courses whose program will be published on the website of the } \\
\text { Romanian Association of Balneology: http://bioclima.ro/ }\end{array}$ \\
\hline
\end{tabular}




\section{Reguli de editare}

(protocol peer-review)

Manuscrisele articolelor vor fi trimise in format Word ataşate unui email la adresa: culturi@gmail.com. Procesarea imaginilor, scanarea şi prelucrarea graficelor - daca este cazul va fi responsabilitatea echipei editoriale. Limba de redactare a articolelor este limba engleza. Articolele pot fi publicate şi cu traducerea lor în limba românã.

După primirea manuscrisului, autorul corespondent va primi un scurt e-mail de confirmare a primirii articolului care va conține numărul de înregistrare, data la care manuscrisul a fost primit şi faptul că manuscrisul a fost înaintat Consiliului Editorial. Editorul revistei alege 2 membrii ai consiliului editorial pentru peer-review şi le trimite prin e-mail manuscrisul.

Decizia recenzorilor (de aprobare, de aprobare cu modificãri minore sau majore, sau de respingere) va fỉ imediat comunicatã prin e-mail autorului corespondent de către editor.

În cazul în care manuscrisul primeşte aprobarea publicãrii cu modificări, autorul corespondent este rugat sã trimitã editorului manuscrisul îmbunătățit în decurs de 4 săptămâni. Editorul revistei va transmite raspunsul autorului corespondent la recenzorii selectaţi. Dacă ei sunt mulţumiţi de modificãrile fãcute, vor trimite editorului decizia de aprobare pentru publicare a manuscrisului îmbunătățit.

În cazul în care recenzorii consideră că autorii nu au respectat acceptabil cererea de revizuire, ei vor putea lua decizia de a nu aproba articolul pentru publicare şi vor comunica decizia respectivã editorului revistei.

Decizia de aprobare pentru publicare luatã de către recenzori va fi comunicată în şedința consiliului editorial.

\section{Editing regulations}

\section{(peer-review protocol)}

The manuscripts will be sumitted as attachement to the email in Word format (to culturi@gmail.com). Photo processing, scanning, graph processing -if needed-are the responsability of the editing team. Language of papers is English. Articles can be published with translation into Romanian.

After manuscript receipt, the corresponding author will receive a short e-mail confirming the receipt, which will contain the registration number, the date the manuscript was received and the fact that the manuscript was handed out to the Editorial Board. The Journal Editor chooses 2 peerreviewers (from the Editorial and Peer-review Board) and sends them by e-mail the manuscript.

The reviewers' decision (approval with no changes, approval with major/minor changes, rejection) will be immediately communicated by e-mail to the corresponding author by the editor.

If the manuscript gets approval with changes, the corresponding author shall send the improved manuscript within 4 weeks. The editor will convey the corresponding author's answer to the peer reviewers. If they are satisfied with the corresponding author's answer, they will send the subject editor the decision of approval for publication of the improved manuscript.

If the peer reviewers consider that the corresponding author did not meet/or met poorly the revision requests, they will deny the approval for publication, which will be communicated to the editor.

The approval for publication once taken by the reviewers, the decision will be communicated in editorial meeting. 
